\title{
Mechanisms Controlling the Dissolved Load, Chemical Weathering and CO2 Consumption Rates of Cauvery River, South India: Role of Secondary Soil Minerals
}

\section{B. Upendra ( $\square$ upendra.ncess@gmail.com )}

National Centre for Earth Science Studies (NCESS)

M. Ciba

National Centre for Earth Science Studies (NCESS)

\section{A. Aiswarya}

National Centre for Earth Science Studies (NCESS)

\section{Vinu Dev}

National Centre for Earth Science Studies (NCESS)

G. Sreenivasulu

National Centre for Earth Science Studies (NCESS)

K. Anoop Krishnan

National Centre for Earth Science Studies (NCESS)

\section{Research Article}

Keywords: solute load, source-wise input, anthropogenic activities, primary rock minerals, secondary soil minerals, silicate weathering rates.

Posted Date: May 4th, 2021

DOl: https://doi.org/10.21203/rs.3.rs-422669/v1

License: (c) (i) This work is licensed under a Creative Commons Attribution 4.0 International License. Read Full License

Version of Record: A version of this preprint was published at Environmental Earth Sciences on February 1st, 2022. See the published version at https://doi.org/10.1007/s12665-022-10222-1. 
1 Mechanisms controlling the dissolved load, chemical weathering

2 and $\mathrm{CO}_{2}$ consumption rates of Cauvery river, South India: Role of

3 secondary soil minerals

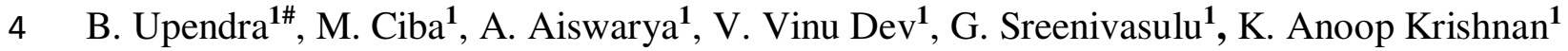

$5{ }^{1}$ National Centre for Earth Science Studies (NCESS), Thiruvananthapuram-11, India.

$6 \quad{ }^{\#}$ Corresponding author. Tel.: +91-0471-251-1700; E-mail address: upendra.ncess@gmail.com 7

8

9

10 


\section{Abstract}

Hydrochemical assessment of the Cauvery River Basin (CRB), an east flowing Western Ghats (WG) river is carried out to understand the dissolved load sources and controlling mechanisms along with quantification of source-wise input to the dissolved load. Silicate weathering rates $(\mathrm{SWR})$ and associated $\mathrm{CO}_{2}$ consumption rates $(\mathrm{CCR})$ are evaluated on account of silicate basement of CRB comprising of granulites and supracrustal rocks. The source-wise solute load contributions estimated using the chemical mass balance model signify that $68 \%$ of total load is from chemical weathering followed by $18.5 \%$ and $13.5 \%$ from anthropogenic and atmospheric inputs respectively, implying that chemical weathering is the major solute load controlling mechanism for CRB. The intensity of silicate chemical weathering occurring in the CRB is measured by index (Re) and found to be $>3$, suggesting an incomplete weathering of drainage rocks (primary minerals) resulting in formation of soils comprising of secondary minerals including oxides, alumino-silicates and clay minerals (smectite, kaolinite and montmorillonite). Detailed understanding of chemical weathering mechanisms is carried out using $\mathrm{Ca} / \mathrm{Na}$ and $\mathrm{Mg} / \mathrm{Na}$ elemental ratios of different end-members including primary minerals from rocks and secondary minerals from soils. The Na-normalized mixing diagram reveals that chemical weathering of secondary minerals is dominating and the solute load contribution to the total dissolved load is significantly higher from secondary minerals (35.5\%) than primary minerals (23.5\%). The SWR and associated CCR are estimated to be $13 \mathrm{t} \cdot \mathrm{km}^{-2} \cdot \mathrm{y}^{-1}$ and $3.3 \times$ $10^{5}$ mole. $\mathrm{km}^{-2} \cdot \mathrm{y}^{-1}$ respectively at outlet (Musiri) of the CRB. Results also indicate that SWR of the east flowing WG river, Cauvery are several times $(\sim 4)$ lower than the average SWR of west flowing WG rivers even though the associated CCR are comparable for both river systems.

Key words: solute load, source-wise input, anthropogenic activities, primary rock minerals, secondary soil minerals, silicate weathering rates. 


\section{1. Introduction}

Dissolved solutes in river waters are acquired by various natural and anthropogenic sources as a result of diverse biogeochemical processes. Among the natural sources, continental weathering and subsequent erosion are the major processes that controls the solute load of river there by transporting materials to ocean realm and geochemical cycling of elements at the Earth's surface. Rock minerals (primary minerals) of Earth's crust can undergo chemical weathering coupled with physical weathering by the action of water in presence of $\mathrm{CO}_{2}, \mathrm{NO}_{2}$, $\mathrm{SO}_{2}$, and $\mathrm{O}_{2}$ resulting in the formation of weathered materials from parent rock consisting of soils with chemically altered minerals (secondary minerals) such as oxides, alumino-silicates, and clay minerals (smectite/kaolinite/montmorillonite) depending on the intensity of weathering. Analogous to primary minerals, secondary minerals in soils can further undergo chemical weathering with higher rates as the surface area of water-soil mineral interaction is higher than the water-rock mineral interaction ${ }^{1-2}$. Chemical weathering of both primary and secondary minerals consumes atmospheric $\mathrm{CO}_{2}$ as dissolved bicarbonates and the amount of $\mathrm{CO}_{2}$ intake depend on the weathering rate of minerals. Silicate weathering has been recognized as the controlling factor on long-term evolution of atmospheric $\mathrm{CO}_{2}$ and hence on Earth's climate ${ }^{3-5}$. The silicate weathering rates (SWR) and associated $\mathrm{CO}_{2}$ consumption rates $(\mathrm{CCR})$ need to be estimated for the global carbon cycle budget modelling and are generally computed from geochemical mass balances of river systems ${ }^{6}$.

In Indian subcontinent, studies related to chemical weathering mainly focus on major ion and isotope characterization as well as the estimation of SWR and associated CCR values for Himalayan rivers ${ }^{7-10}$ and for smaller rivers draining the deccan basalt ${ }^{11-12}$. Studies on peninsular rivers comprise of Braun et al. ${ }^{2}$ (Kabini), Gupta et al. ${ }^{13}$ (Narmada), Gurumurthy et $a l .{ }^{5}$ (Netravati), Pattanaik et al. ${ }^{14}$ (Cauvery) and Thomas et al..$^{15}$ (Pambar), carried out the hydrochemical characterization along with estimation of SWR and associated CCR. However, 
1 studies related to understanding the importance of secondary minerals in chemical weathering

2 and quantification of their contribution to the dissolved load at river basin scale are sparse.

3 Violette et al. ${ }^{16}$ attempted to understand the role of secondary minerals in chemical weathering

4 through modelling approach in an experimental watershed, the Mule hole. Gurumurthy et al. ${ }^{17}$

5 used $\mathrm{Sr}$ isotope ratios to assess the role of secondary minerals in chemical weathering of

6 Netravati river and proposed that solute contribution from secondary minerals is significant to

7 the river load during monsoon season compared to the pre-monsoon.

The study area, Cauvery River Basin (CRB) comprise of varying lithological compositions, elevations and climatic conditions which play a crucial role in rock (primary minerals) weathering that underpins the formation of weathered materials consisting of soils highly characterized by secondary minerals from upstream to downstream ${ }^{18-19}$. Many studies reported that industrial and urban waste are polluting the tributaries of Cauvery river along its course at many places due to increased developmental activities ${ }^{20-22}$. Pattanaik et al ${ }^{14,23}$ studied the Sr isotopic ratios and major ion chemistry of Cauvery river, concluded that more than $90 \%$ of the total dissolved load is derived from weathering of silicate rocks and also estimated the SWR and associated CCR values. However, previous studies have not elaborated the anthropogenic impacts on the dissolved load and the role of secondary minerals in chemical weathering. Present study emphasizes the source-wise solute load quantification, role of secondary minerals and anthropogenic activities in controlling the dissolved load of CRB followed by the estimation of weathering index (Re), SWR and associated CCR.

\section{Materials and methods}

\subsection{Study area}

The Cauvery river (Fig. 1) originates from Brahmagiri hill range of Western Ghats (WG) at an elevation $1341 \mathrm{~m}$ situated in the Coorg district of Karnataka, South India and drains an area of 81,155 sq.km with a total length of $800 \mathrm{~km}$ from origin to outfall. In South India, 
1 the CRB possess high socio-economic significance as the river basin drains through several

2 hectares of agricultural land. Temperature of the CRB varies from upper reaches to the plain

3 regions mainly due to altitude variations ${ }^{24}$. Rainfall varies considerably across the basin,

4 western side of basin receives higher rainfall during southwest monsoon (Jun to Sep) up to

5 Mettur dam, while southeastern portion receives higher rainfall during the northeast monsoon

6 (Oct to Dec) seasons ${ }^{25}$. Water balance $\operatorname{study}^{26}$ of the CRB reveals that evapo-transpiration is

7 higher than water yield during February to June months due to higher temperatures during

8 summer. Land use land cover analysis of CRB in 2005 reveals that agricultural land is dominant

9 in the basin $(66.21 \%)$ followed by forest area (20.5\%), built up area (4.01\%) and waste land

10 (3.86\%). However, the land use land cover analysis of CRB in 2014 claims that, forest land has

reduced due to agricultural activities while built up area increased due to rapid socio-economic developments ${ }^{24}$. Soil types vary across the basin, mostly possessing red soils followed by black, mixed, alluvial and lateritic soils http://karenvis.nic.in/Databse/Natural_Resources_7958.aspx. Moreover, trivial amounts of pedogenic carbonate accumulation is found at some places characterized by lower than average rainfall of WG within the $\mathrm{CRB}^{27-28}$.

The CRB forms the part of South Indian shield that constitute the igneous and metamorphic rocks of Precambrian age and sedimentary rocks (Fig. S1) of late Jurassic to recent age ${ }^{29-30}$ and possess geological significance as the river basin undergo several tectonicsedimentary evolutionary phases. Geologically, CRB constitutes two geological terrains northern greenstone terrain (Dharwar Craton) and southern granulite terrain (SGT) separated by a transition zone. Northern greenstone terrain comprises of rocks of granitic composition included with supracrustal belts metamorphosed to lower than amphibolite facies such as tonalite-trondhjemite and granodiorite. Southern granulite terrain comprises of granitic and supracrustal belts that are metamorphosed to granulite grade resulting in rock like charnockite, pyroxene granulite and high-grade metamorphic assemblages. Closepet granite intruded into 
1 gneiss, charnockites as large block mountain masses at the south of transition zone ${ }^{18,31}$.

2 Carbonatites hosted within pyroxenite dikes intruded into the charnockites are found in a

3 smaller area of Hogenakkal region ${ }^{32}$. Lower part of the basin (below Musiri) comprises of

4 faunal rich sedimentary rocks such as limestone, sandstones and quaternary sediments $\mathrm{s}^{33}$.

\section{$5 \quad 2.2$ Hydrochemical data}

Present study uses the multiannual hydrochemical data of Cauvery river provided by the Central Water Commission (CWC), an organization of Ministry of Water Resources, Government of India. CWC has a large number of river monitoring sites called hydrological observatory (HO) stations for Indian rivers. The hydrological as well as hydrochemical data obtained from these stations are available with Water Resources Information System of India http://indiawris.gov.in/wris/\#/SWQuality. There are six HO stations that exist along the main channel of the Cauvery river from upstream to downstream ${ }^{24}$ (Cauvery basin report, 2014) and their locations are shown in the base map, Figure 1. Among these HO stations, 'Kudige' is located in the upstream region and 'Musiri' is located at farthest downstream region covering an area of $66,243 \mathrm{~km}-2$ which is almost $82 \%$ of the $\mathrm{CRB}^{34}$. Hydrochemical data of these six $\mathrm{HO}$ stations are considered for the present study, where the parameters like $\mathrm{Na}, \mathrm{K}, \mathrm{Ca}, \mathrm{Mg}$, $\mathrm{SiO}_{2}, \mathrm{Cl}, \mathrm{SO}_{4}$ and $\mathrm{HCO}_{3}, \mathrm{pH}, \mathrm{EC}$, TDS and discharge data collected on monthly basis for the years 2011 - 15 are used and their seasonal average values are provided in Table 1. Further, this hydrochemical data is validated by using the normalized inorganic charge balance (NICB) test, using the following equation.

$\mathrm{NICB}=\left[\left(\mathrm{Tz}^{+}-\mathrm{Tz}^{-}\right) /\left(\mathrm{Tz}^{+}+\mathrm{Tz}^{-}\right)\right] \times 100 \%$

NICB is the extent of deviation between sum of cations charge $\left(\mathrm{Tz}^{+}\right)$and sum of anions charge $\left(\mathrm{Tz}^{-}\right)$expressed in equivalents. The NICB values (Table 1) are generally within $10 \%$ for all the data points used, suggesting that major ions are by and large balanced. In addition, the scatter plot between $\mathrm{Tz}^{+}$and $\mathrm{Tz}^{-}$shows good correlation (Fig. 2a), indicating that the data is highly 
1 reliable ${ }^{35}$. Variation in the multiannual hydrochemical data presented in the box plot of Fig. 2b,

2 shows significant variations among all the dissolved solutes, indicating the prominent spatio-

3 temporal differences in the river water chemistry.

In following sections, the validated hydrochemical data is used for appraising the dissolved load sources, controlling factors and chemical weathering mechanisms along with the quantification of source-wise input, silicate weathering index $(\mathrm{Re})$, chemical weathering and $\mathrm{CO}_{2}$ consumption rates. Relative importance of various solute acquisition mechanisms viz. atmospheric precipitation, water-mineral interaction, evaporation-crystallization and anthropogenic activities are deciphered by different ionic ratios and relations perceived through scatter diagrams including the Gibbs model of TDS vs $\mathrm{Na} /(\mathrm{Na}+\mathrm{Ca})$. The source-wise input to the total dissolved load is determined by using the chemical mass balance model based on the major ion concentrations. Silicate weathering index is used for measuring the intensity of silicate chemical weathering occurring in the drainage basin. Mixing analysis of Na-normalized elemental ratios of different end-members is followed to understand chemical weathering input from various geochemical species to the dissolved load. Further, the implications of chemical weathering in the drainage basin are realized by estimating the SWR and associated CCR.

\section{Results and discussions}

\subsection{Sources and mechanisms controlling the dissolved load}

Sources of dissolved solutes in the river waters ${ }^{36-37}$ are mainly (1) Cyclic salts which are precipitation inputs carried from ocean to land and modified by the atmospheric processes (2) Anthropogenic inputs including solid and liquid wastes from settlements, seepages, agricultural and industrial activities, etc. (3) Water-mineral interaction products including the chemical weathering of drainage minerals. 
2 precipitation, water-rock/soil interaction and evaporation. Gibbs diagram for the CRB waters

3 (Fig. 3a) shows the dominance of water-rock/soil interaction. Nevertheless, samples are not

4 clustered at one point due to increasing TDS concentrations from upstream to downstream,

5 rather range from precipitation-dominated to evaporation-dominated region with most samples

6 are classified under water-rock/soil interaction. This resembles the impact of excessive

7 chemical weathering, influence of anthropogenic activities and climatic conditions in the

8 drainage basin (sub-humid climate in upstream region to semi-arid in downstream). In addition,

9 the scatter plot (Fig. 3b) of $\mathrm{HCO}_{3}$ and $\mathrm{Na}+\mathrm{K}+\mathrm{Ca}+\mathrm{Mg}$ (total cations) shows good correlation

10 among them $\left(\mathrm{R}^{2}=0.815\right)$, suggesting that the common source for all these ions is most possibly

11 the chemical weathering of drainage minerals. However, the deviation from 1:1 towards total cation concentrations indicate the sources other than chemical weathering, most probably the anthropogenic activities yielding significant concentrations of Na. Thus, both Gibbs model and scatter plot of $\mathrm{HCO}_{3}$ vs total cations emphasize that water-rock/soil interaction thereby the chemical weathering of drainage minerals is the major solute acquisition mechanism for CRB.

Scatter plot of $\mathrm{Na} / \mathrm{Cl}$ versus $\mathrm{Cl}$ is used to characterize the relative importance of solute sources like cyclic salts, anthropogenic activities and silicate weathering. $\mathrm{Na} / \mathrm{Cl}$ ratio below 0.86 indicates cyclic salt sources, whereas the ratio close to $1: 1$ indicates the addition of both $\mathrm{Na}$ and $\mathrm{Cl}$ due to a common source (evaporite dissolution or anthropogenic activities) and the ratios greater than 1:1 generally interpreted as the addition of $\mathrm{Na}$ by silicate weathering. Fig. 4a shows $\mathrm{Na} / \mathrm{Cl}$ versus $\mathrm{Cl}$ plot for the $\mathrm{CRB}$, indicates the presence of all the aforesaid processes. Considering the study area, significant amount of $\mathrm{Cl}$ is being added up linearly from upstream (Kudige) to downstream (Musiri) region as shown in Fig 4 b. Since there are no evaporite minerals present in the study area, these higher concentrations of $\mathrm{Cl}$ most likely originated from the anthropogenic activities that are markedly increase downstream along the river course. 
1 Moving from the upstream to the downstream, Cauvery river is flowing through industrial,

2 agricultural and settlement areas. The middle and downstream regions of Cauvery main stream

3 is merges with its most polluted tributaries, Amaravathi and Noyyal which are the carriers of

4 industrial and sewage effluents to the main streams of Cauvery ${ }^{20-22}$. Thus, impact of

5 anthropogenic activities can be clearly seen on the solute load of CRB moving to down reaches.

\section{6}

7

8

\subsection{Degree of chemical weathering - evidence for secondary soil minerals}

To account for the intensity of silicate rock weathering occurring in the CRB, degree of silicate chemical weathering is determined by using the index (Re) proposed by Tardy ${ }^{39}$. This index is based on the number of cations released into water relative to silica and alumina which is in turn related to the mean chemical composition of bed rock minerals and is as follows ${ }^{40}$.

$$
\mathrm{Re}=\frac{3 \mathrm{Na}+3 \mathrm{~K}+2 \mathrm{Ca}-\mathrm{SiO}_{2}}{\mathrm{Na}+\mathrm{K}+\mathrm{Ca}}
$$

In the above equation (2), coefficients are derived from the chemical composition of minerals present in the drainage basin excluding the $\mathrm{Mg}$ minerals as the entire basin is composed of felsic minerals. However, present study uses slightly modified equation in order to incorporate $\mathrm{Mg}$ minerals like biotite, hypersthene and hornblende found in CRB along with the felsic minerals present in the granite substratum. The modified weathering index equation is likely;

$$
\mathrm{Re}=\frac{3 \mathrm{Na}+3 \mathrm{~K}+2 \mathrm{Ca}+3.6 \mathrm{Mg}-\mathrm{SiO}_{2}}{0.5 \mathrm{Na}+0.5 \mathrm{~K}+\mathrm{Ca}+1.46 \mathrm{Mg}}
$$

In this equation (3), coefficients are derived based on following mineral compositions; feldspar minerals including orthoclase, anorthite, albite and mafic minerals covering biotite, hypersthene and hornblende. Re values of 0,2 and 4 corresponds to allitization (formation of Gibbsite and Goethite), monosiallitization (formation of Kaolinite) and bisiallitization (formation of Smectites) respectively ${ }^{39-40}$. If the value of $\operatorname{Re}>2$, but varies between 2 to 4 , indicating formation of chlorite, montmorillonite, illite, vermiculite, and sericite. Considering $\mathrm{CRB}$, the Re values vary between 2 to 4 over different parts of the study area with a discharge 
1 weighted average of 3.3 indicating bisiallitization stage of weathering (less intense weathering)

2 i.e., incomplete weathering with formation of kaolinite, chlorite, montmorillonite and smectite mineral assemblages in soils. Further, abundance of these secondary minerals in CRB

4 evidenced by studies of Sharma and Rajamani ${ }^{18}$; Tripathi and Rajamani ${ }^{31}$; Rajamani et al. ${ }^{19}$.

\section{$5 \quad 3.3$ Elemental ratios of different end-members- mixing analysis}

In order to account for the chemical weathering input from different geochemical endmembers, present study uses the modified Na-normalized Ca versus Mg mixing diagram by defining ' 3 ' different geochemical end-members in terms of $\mathrm{Ca} / \mathrm{Na}$ and $\mathrm{Mg} / \mathrm{Na}$ molar ratios primary silicate minerals from rocks, secondary silicate minerals from soils and carbonate minerals. The primary (rock) minerals end-member is developed following Rao et al. ${ }^{41}$; Sharma and Rajamani ${ }^{18}$; Jayananda et al. ${ }^{42}$; Tomson et al. ${ }^{43}$; Rajamani et al. ${ }^{19}$; Braun et al. ${ }^{2}$. The carbonate end-member is developed from geochemical composition of Hogenakkal carbonatite by Pandit et $a l .{ }^{32}$ and from the study by Violette $e t a l .{ }^{28}$ about the geochemistry of calcretes (pedogenic carbonates). Finally, the secondary soil minerals end-member is developed by using the weathered profile geochemical data provided by Sharma and Rajamani ${ }^{18}$; Tripathi and Rajamani ${ }^{31}$; Rajamani et al. ${ }^{19}$. The molar ratios of $\mathrm{Ca} / \mathrm{Na}$ and $\mathrm{Mg} / \mathrm{Na}$ estimated for various end-members from the previous studies are provided in Table 2.

The Na-normalized mixing diagram thus developed along with the river water samples is shown in Fig. 5, which is slightly different from the Na-normalized mixing diagram used by various researchers ${ }^{5,14,44}$ as it involves an additional end-member, 'secondary minerals' representing the secondary silicate minerals in soils. Accordingly, the $\mathrm{Na}$ - normalized $\mathrm{Ca}$ versus $\mathrm{Mg}$ mixing diagram of $\mathrm{CRB}$ shows the aforementioned ' 3 ' general end-members. Primary minerals end-member is generated by taking into account all the major silicate rocks, while the carbonate end-member is determined by taking all the carbonate sources and the secondary minerals end-member is developed by considering the silicate minerals in soils of 
1 each major lithology exposed from upstream to downstream. In the Na-normalized mixing

2 diagram, granite and granodiorite show the lowest $\mathrm{Ca} / \mathrm{Na}$ and $\mathrm{Mg} / \mathrm{Na}$ values while the other

3 silicate rock types gneiss, biotite gneiss, charnockite and felsic granulites are lying almost

4 closely. The average $\mathrm{Ca} / \mathrm{Na}$ and $\mathrm{Mg} / \mathrm{Na}$ values of these silicate rocks is handled as primary

5 minerals end-member which is similar to the silicate end-member range developed by

6 Gaillardet et $a l .{ }^{45}$. The carbonate end-member shows the highest $\mathrm{Ca} / \mathrm{Na}$ and $\mathrm{Mg} / \mathrm{Na}$ values and

7 is similar to the carbonates end-member range developed by Gaillardet et $a l .{ }^{45}$. Third end-

8 member secondary minerals which is exclusive to the CRB, not falling in the mixing line

9 between primary minerals and carbonate end-members rather follows a triangular relation with

10 the latter two end-members indicating that secondary minerals end-member is characterized by rather higher $\mathrm{Mg} / \mathrm{Na}$ values than the $\mathrm{Ca} / \mathrm{Na}$ values. The Na-normalized diagram of $\mathrm{CRB}$ with water samples (Fig. 5) show a mixing between primary and secondary mineral end-members along the $\mathrm{Mg} / \mathrm{Na}$ axis, with most of the samples showing a trend more towards the secondary minerals end-member than the carbonate. This emphasize that most of the $\mathrm{Mg}$ in CRB is derived from the weathering of primary and secondary minerals with negligible contribution from carbonates. This leads to the inference that $\mathrm{Mg}$ sources in CRB river water is entirely from silicate minerals not exclusively from primary silicate minerals but with significant contribution from secondary silicate minerals. This can be due to higher rates of chemical weathering of secondary minerals present in soils than that of primary minerals in rocks. Apart from the $\mathrm{Mg}$ acquisition processes, the Na-normalized mixing diagram (Fig. 5) also infer that $\mathrm{Ca}$ in $\mathrm{CRB}$ is derived from chemical weathering of all the ' 3 ' end-members - primary rock minerals, secondary soil minerals and carbonates. 
1 The chemical mass balance model $1^{19,46-48}$ is used to decipher the contribution of different

2 sources to the total dissolved load. Accordingly, chemical mass budget equation for any solute

3 ' $\mathrm{X}$ ' in the dissolved load of CRB is given by:

$4 \quad X_{\mathrm{rw}}=X_{\mathrm{atm}}+X_{\text {anthro }}+X_{\text {chem.weath }} ;$ such that $X_{\text {chem.weath }}=X_{\text {primary }}+X_{\text {secodary }}+X_{\text {carb }}$

5 where rw, atm, anthro and chem.weath are river water, atmospheric input, anthropogenic input

6 and chemical weathering inputs respectively. Primary, secondary and carb are inputs from

7 primary minerals, secondary minerals and carbonate respectively.

\section{$8 \quad 4.1$ Atmospheric input}

Quantification of solute load from atmospheric processes to the river waters is estimated using the equation (5), where chloride $(\mathrm{Cl})$ is being used as the proxy due to its conservative nature through hydrological cycle within the watershed ${ }^{1,49}$.

$\mathrm{X}_{\mathrm{atm}}=(\mathrm{X} / \mathrm{Cl})_{\text {rain }} \times \mathrm{Cl}_{\mathrm{ref}}$

where $\mathrm{X}_{\mathrm{atm}}$ is the molar concentrations of atmospheric input for a given element $\mathrm{X}(=\mathrm{Na}, \mathrm{K}$, $\mathrm{Ca}$ and $\mathrm{Mg})$ and $(\mathrm{X} / \mathrm{Cl})_{\text {rain }}$ is the $\mathrm{X} / \mathrm{Cl}$ molar ratios of rainwater. $\mathrm{Cl}_{\text {ref }}$ is the critical chloride concentration that accounts for evapo-transpiration, atmospheric wet and dry deposition processes. In order to estimate the $\mathrm{Cl}_{\text {ref }}$ values, rainwater chloride concentration is multiplied by ' $F_{\text {et }}$ ' to account for concentration effects of evapo-transpiration and ' $F_{\text {deposition' }}$ ' to account for interception deposition and effects of canopy such that, $\mathrm{Cl}_{\mathrm{ref}}=\mathrm{Cl}_{\mathrm{rain}} \times \mathrm{F}_{\mathrm{et}} \times \mathrm{F}_{\mathrm{deposition}}$. This $\mathrm{Cl}_{\text {ref }}$ is used for further quantification purposes which results in providing the maximum ${ }^{1}$ atmospheric input (upper limit) possible to the river waters rather than simply using the rainwater chloride concentration alone. The factor ' $F_{\text {et }}$ ' calculated by using the rainfall and runoff data is estimated to be 1.97 for CRB based on the study by Zade et al. ${ }^{50}$. Rainwater chemical composition obtained from the study of Rao et $a l .{ }^{41}$ is used for quantification and provided in Table S1. Rao et al. ${ }^{41}$ reported the rainwater and throughfall chemical composition 
1 at Silent Valley (Nilgiri hills region within CRB) and concluded that ionic concentrations in

2 throughfall are higher than the rainwater due to interception deposition as well as cycling of

3 chemical species by canopy. Thus, the effects of deposition and canopy leaching are counted

4 by the factor ' $\mathrm{F}_{\text {deposition' }}$ and is taken as the ratio of $\mathrm{Cl}$ concentration in throughfall to rainfall

5 (Table S1) which is about 1.88. The estimated values of atmospheric input to the total dissolved

6 load (Fig. 6) vary from $21.5 \%$ at upstream (Kudige) to $6.5 \%$ at downstream (Musiri) regions

7 with a discharge weighted average contribution of $13.5 \%$ for the whole basin. This indicates

8 that solute load contribution from atmospheric processes to the total dissolved of CRB is minor.

$9 \quad 4.2$ Anthropogenic input

Anthropogenic input to the river load can be quantified using the values of $\mathrm{Cl}_{\text {ref }}$ assuming that there are no other sources such as evaporites for chloride except atmospheric and anthropogenic, which is indeed valid for CRB. If the chloride concentration measured in the river water is less than $\mathrm{Cl}_{\text {ref, }}$, then the whole chloride in river water is assigned to atmospheric origin and if it is more than $\mathrm{Cl}_{\text {ref }}$, then the atmospheric input correction is applied with $\mathrm{Cl}_{\text {ref }}$ and the residual chloride $\left(\mathrm{Cl}_{\text {res }}\right)$ in the river water is attributed to anthropogenic input ${ }^{1}$. This $\mathrm{Cl}_{\mathrm{res}}$ is of anthropogenic origin and is balanced by the anthropogenic sodium ( $\left.\mathrm{Na}_{\text {anthro }}\right)$ in the dissolved load considering the presence of significant anthropogenic activities in the study area (section 3.1).

$\mathrm{Cl}_{\text {res }}=\mathrm{Cl}_{\text {anthro }}=\mathrm{Cl}_{\text {riverwater }}-\mathrm{Cl}_{\mathrm{re}}$

$\mathrm{Cl}_{\text {anthro }}=\mathrm{Na}_{\text {anthro }}$

21 The estimated values of anthropogenic input to the total dissolved load (Fig. 6) vary from $10 \%$ at upstream (Kudige) to $26 \%$ at downstream (Musiri) regions with a discharge weighted average contribution of $18.5 \%$ for the whole basin. This indicates that solute load contribution 
1 from anthropogenic activities is significant and that about one-fifth of total solute load is from

2 anthropogenic origin in the case of CRB.

3

4

5

6

7

8

9

\subsection{Silicate weathering input - primary minerals}

Solute load to the river water through chemical weathering of silicate rocks can be quantified using suitable proxies such as atmospheric input corrected $\mathrm{Na}\left(\mathrm{Na}^{*}\right)^{5}$, atmospheric and anthropogenic input corrected $\mathrm{Na}\left(\mathrm{Na}_{\mathrm{sil}}\right)^{46,51-52}$ or atmospheric input corrected $\mathrm{Mg}\left(\mathrm{Mg}^{*}\right)^{12}$ concentrations in river waters. $\mathrm{Na}$ in the Cauvery river waters is supplied from atmospheric input, anthropogenic activities and silicate weathering sources, contribution of $\mathrm{Na}$ from silicate weathering can be estimated after correcting $\mathrm{Na}$ river water concentrations $\left(\mathrm{Na}_{\mathrm{rw}}\right)$ for atmospheric $\left(\mathrm{Na}_{\mathrm{atm}}\right)$ and anthropogenic $\left(\mathrm{Na}_{\text {anthro }}\right)$ inputs by using the $\mathrm{Cl}_{\text {ref. }}$ To calculate the silicate contribution of $\mathrm{K}$ in the $\mathrm{CRB}$, it is assumed that all the $\mathrm{K}$ in river waters are derived from atmospheric input and silicate weathering. The residual $\mathrm{K}$ in river waters after the correction of atmospheric inputs is assigned to silicate weathering. The silicate weathering contributions of $\mathrm{Ca}$ and $\mathrm{Mg}$ are estimated by using silicate component of $\mathrm{Na}\left(\mathrm{Na}_{\text {sil }}\right)$ as the proxy based on two general assumptions ${ }^{5,53-54}$. First, $\mathrm{Ca}_{\text {sil }}$ and $\mathrm{Mg}_{\text {sil }}$ are released in to the river waters in a fixed proportion relative to $\mathrm{Na}$ from the silicate minerals and the second, anthropogenic contributions of $\mathrm{Ca}$ and $\mathrm{Mg}$ are negligible. In this case, silicate weathering component budget equations are given by;

$\mathrm{Na}_{\mathrm{sil}}=\mathrm{Na}_{\mathrm{rw}}-\mathrm{Na}_{\mathrm{atm}}-\mathrm{Na}_{\mathrm{anthro}}$

$\mathrm{K}_{\mathrm{sil}}=\mathrm{K}_{\mathrm{rw}}-\mathrm{K}_{\mathrm{atm}}$

$\mathrm{Ca}_{\text {sil }}=\mathrm{Na}_{\text {sil }} \times(\mathrm{Ca} / \mathrm{Na})_{\text {rock }}$

$\mathrm{Mg}_{\text {sil }}=\mathrm{Na}_{\text {sil }} \times(\mathrm{Mg} / \mathrm{Na})_{\text {rock }}$

where the subscripts sil, rw, atm and anthro refers to silicate, river water, atmosphere and anthropogenic input respectively; $(\mathrm{Ca} / \mathrm{Na})_{\text {rock }}$ and $(\mathrm{Mg} / \mathrm{Na})_{\text {rock }}$ are the ratios of $\mathrm{Ca}$ and $\mathrm{Mg}$ with 
1 which they released into river waters relative to $\mathrm{Na}$ from silicates. In the case of $\mathrm{CRB}$, up to

2 the farthest downstream station Musiri, values of $(\mathrm{Ca} / \mathrm{Na})_{\text {rock }}$ and $(\mathrm{Mg} / \mathrm{Na})_{\text {rock }}$ are taken as 0.7

3 and 0.5 respectively, following the values of average silicate end-member (Fig. 5) based on the

4 mean rock composition. The estimated values of silicate weathering input (Fig. 6) to the total

5 dissolved load vary from $53 \%$ at upstream (Kudige) to $60 \%$ at the downstream (Kodumudi)

6 regions with a discharge weighted average contribution of $59 \%$ for the whole basin, which

7 indicate that the contribution of silicate weathering input is more pronounced.

\section{$8 \quad 4.4$ Chemical weathering input: Primary rock vs secondary soil minerals}

Dissolved solutes in Cauvery river waters are largely made up of water-rock/soil interaction process (Fig. $4 \mathrm{a}$ and $4 \mathrm{~b}$ ) leading to the chemical weathering of drainage minerals derived from primary rocks and secondary soils as discussed in section 3.1. However, solute load contribution from chemical weathering of each source (primary vs secondary) is characteristic to the basin and depends on degree of weathering of the drainage basin, i.e., how well the terrain is drained. For example, intense weathering of rock associated with high erosion rates leads to thin soil cover, rich in secondary minerals such as goethite and gibbsite. The less intense/moderate weathering is associated with less erosion rates that results in thick soils abundant in secondary mineral assemblages (chlorite/smectite/kaolinite) in the river basin. Further, interaction between water and soil minerals occur in different ways such as chemical weathering, cation exchange and adsorption ${ }^{55}$, out of which chemical weathering of the secondary soil minerals is the dominant process which depends on the residence time of water on soil ${ }^{56}$. As described in section 3.2 , chemical weathering of secondary soil minerals is influencing the dissolved load of Cauvery river along with primary rock minerals. In this section, the contribution of primary and secondary minerals to the total dissolved load is quantified assuming that all the $\mathrm{Mg}$ in Cauvery river waters is derived from rain input, silicate weathering of both primary and secondary minerals and negligible contribution from carbonate 
1 minerals. The following equations (12-15) are used to calculate the solute load contribution

2 from chemical weathering of secondary soil minerals.

3

$4 \quad \mathrm{Mg}_{\text {primary }}=\mathrm{Mg}_{\text {sil }}$

5

$6 \quad \mathrm{Ca}_{\text {secondary }}=\mathrm{Mg}_{\text {secondary }} \times(\mathrm{Ca} / \mathrm{Mg})$ soil

7 where $\mathrm{Ca}_{\text {primary }}, \mathrm{Mg}_{\text {primary }}, \mathrm{Ca}_{\text {secondary }}$ and $\mathrm{Mg}_{\text {secondary }}$ are concentrations of $\mathrm{Ca}$ and $\mathrm{Mg}$ released into the river waters during chemical weathering of silicate minerals present in rocks and soils respectively. $(\mathrm{Ca} / \mathrm{Mg})$ soil is the ratio of $\mathrm{Ca}$ with which they are released into river waters relative to $\mathrm{Mg}$ from silicate minerals present in soils. The computed values of solute load contribution from the primary minerals (Fig. 7) to the total dissolved load vary from $15.5 \%$ at upstream (Kudige) to $37.5 \%$ at middle (Biligundulu) regions with a discharge weighted average contribution of $23.5 \%$ for the whole basin. Similarly, the estimated values of solute load contribution from the secondary minerals to the total dissolved load varies from $37 \%$ at upstream (Kudige) to $44 \%$ at the downstream (Urachikottai) regions with a discharge weighted average contribution of $35.5 \%$ for the whole basin, indicating that the weathering contribution of secondary minerals is significantly higher than the primary minerals. This shows that chemical weathering of secondary minerals from soils is the dominant solute acquisition mechanism for CRB.

\subsection{Carbonate weathering input}

It is found that the $\mathrm{Ca}$ concentrations in river waters $\left(\mathrm{Ca}_{\mathrm{rw}}\right)$ are higher than the sum of Ca contributed from atmospheric input $\left(\mathrm{Ca}^{*}\right)$ and silicate weathering $\left(\mathrm{Ca}_{\text {sil }}\right)$ estimated in the sections 4.1 and 4.3. This indicates that, there are additional sources of $\mathrm{Ca}$ other than silicate weathering as depicted from the Na-normalized mixing diagram (Fig. 5). Evaluating the study 
1 area, the additional sources of $\mathrm{Ca}$ might be due to the trivial occurrence of carbonatites and

2 calcretes in $\mathrm{CRB}$. The residual excess of $\mathrm{Ca}$ in rivers waters after the correction of atmospheric

3 input and silicate weathering is then allocated to carbonate weathering ${ }^{12}$. Thus, solute load due

4 to chemical weathering of scarcely present carbonates in CRB can be quantified using the

5 silicate weathering yields of $\mathrm{Ca}\left(\mathrm{Ca}_{\text {sil }}\right)$. Subsequently, the carbonate weathering component

6 budget equation is given by;

$7 \quad \mathrm{Ca}_{\mathrm{carb}}=\mathrm{Ca}_{\mathrm{rw}}-\mathrm{Ca}_{\mathrm{atm}}-\mathrm{Ca}_{\text {sil }}$

8 where the subscripts carb, rw, atm and sil refers to carbonate, river water, atmosphere and

9 silicate respectively. The quantified carbonate weathering input (Fig. 6) to the total dissolved load vary from $21 \%$ at upstream (Kollegal) to $10 \%$ at the downstream (Musiri) regions with a discharge weighted average contribution of $9 \%$ for the whole basin. This indicates that the contribution of carbonate weathering input is significantly lower than the silicate weathering input and shows overall control of silicate weathering on solute chemistry. Together, both the silicate and carbonate chemical weathering inputs represent $68 \%$ of the total dissolved load which imply that water-rock/soil interaction is the critical solute acquisition process for CRB.

\section{Chemical weathering and $\mathrm{CO}_{2}$ consumption rates}

Chemical weathering rates depend on various factors; temperature, precipitation, composition of parent rock, biological effects etc. Though different methods are available to compute chemical weathering rates ${ }^{57-59}$, present study uses the river water hydrochemistry, drainage area and amount of discharge $e^{53,12}$ to compute them.

\subsection{Silicate and Carbonate weathering rates of CRB}

The silicate weathering rates (SWR) of the CRB are estimated by using the following equation $^{5,12,47}$. 
1 where $\mathrm{Q}$ is the discharge in $\mathrm{m}^{3} \cdot \mathrm{sec}^{-1}, \mathrm{~A}$ is surface area of the basin in $\mathrm{km}-2,(\mathrm{Na}+\mathrm{K}+\mathrm{Ca}+\mathrm{Mg})_{\text {sil }}$

2 and $\mathrm{SiO}_{2}$ are the silicate weathering derived total cation and silica concentrations $(\mathrm{mg} / \mathrm{L})$ of the

3 river water and the final values are reported in units of $t . \mathrm{km}^{-2} \cdot \mathrm{y}^{-1}$ with appropriate conversion

4 factors. The SWR of the CRB vary from 13 to $61 \mathrm{t} \cdot \mathrm{km}^{-2} \cdot \mathrm{y}^{-1}$ with a value of $13 \mathrm{t} \cdot \mathrm{km}^{-2} \cdot \mathrm{y}^{-1}$ at the

5 outlet of the basin (Musiri), which is slightly higher than the previously reported values of 9.5

6 t. $\mathrm{km}^{-2} \cdot \mathrm{y}^{-1}$ by Pattanaik et al. ${ }^{14}$. This difference must be attributed to the modelling approach of

7 estimating the relative contributions from silicate and non-silicate sources to the dissolved load

8 of river water. Though, both studies use the elemental ratios mixing analysis approach, study

9 by Pattanaik et al. ${ }^{14}$ is based on $\mathrm{Ca} / \mathrm{Sr}$ versus $\mathrm{Mg} / \mathrm{Sr}$ ratios of primary minerals only while the

10 present study is based on $\mathrm{Ca} / \mathrm{Na}$ versus $\mathrm{Mg} / \mathrm{Na}$ ratios of primary minerals as well as secondary minerals. Comparing the east and west flowing WG river systems, the average SWR reported for west flowing rivers $53 \mathrm{t} \cdot \mathrm{km}^{-2} \cdot \mathrm{y}^{-1} 5,12$ is several times ( 4 times) higher than the SWR of the east flowing Cauvery river. Similarly, SWR of other Peninsular rivers such as Krishna (14 t. $\left.\mathrm{km}^{-2} \cdot \mathrm{y}^{-1}\right)^{45}$ are comparable to the CRB. Further, the Himalayan river systems such as Ganga (10.2 - 15.2 t. $\left.\mathrm{km}^{-2} \cdot \mathrm{y}^{-1}\right),{ }^{60,45-46}$, Brahmaputra $\left(10.3 \mathrm{t} \cdot \mathrm{km}^{-2} \cdot \mathrm{y}^{-1}\right)^{45}$ shows comparable SWR with Cauvery while Yamuna $\left(28 \mathrm{t} \cdot \mathrm{km}^{-2} \cdot \mathrm{y}^{-1}\right)^{46}$ has higher and Indus $\left(3.8 \mathrm{t} \cdot \mathrm{km}^{-2} \cdot \mathrm{y}^{-1}\right)^{45}$ has lower SWR than Cauvery. Comparing the SWR of Cauvery with world rivers, it is found that Cauvery has higher SWR than the rivers draining in cratonic/shield area such as Mackenzie $\left(1.8 \mathrm{t} \cdot \mathrm{km}^{-2} \cdot \mathrm{y}^{-1}\right)$, Congo-Zaire $\left(4.22 \mathrm{t} . \mathrm{km}^{-2} \cdot \mathrm{y}^{-1}\right)$, Parana $\left(5 \mathrm{t} . \mathrm{km}^{-2} \cdot \mathrm{y}^{-1}\right)^{45}$, Niger, Congo and Nyong $(5.33 \pm 1.17$ t.km $\left.{ }^{-2} \cdot \mathrm{y}^{-1}\right)^{61}$, Cameron $\left(7 \mathrm{t} \cdot \mathrm{km}^{-2} \cdot \mathrm{y}^{-1}\right)^{62}$ and Toctatins $\left(7.5 \mathrm{t} \cdot \mathrm{km}^{-2} \cdot \mathrm{y}^{-1}\right)^{45}$, whereas Cauvery has similar SWR values to Orinoco river $\left(9.5 \mathrm{t} \cdot \mathrm{km}^{-2} \cdot \mathrm{y}^{-1}\right)$ and the Amazon river $\left(13 \mathrm{t} \cdot \mathrm{km}^{-2} \cdot \mathrm{y}^{-1}\right)^{45}$. equation $^{12,47}$. 
1 where $\mathrm{Q}$ is the discharge in $\mathrm{m}^{3} \cdot \mathrm{sec}^{-1}, \mathrm{~A}$ is the surface area of the basin in $\mathrm{km}^{2}$ and $(\mathrm{Ca}+\mathrm{Mg})_{\text {carbo }}$

2 is the carbonate weathering derived concentrations $(\mathrm{mg} / \mathrm{L})$ of the dissolved $\mathrm{Ca}$ and $\mathrm{Mg}$ in river water and the final values are reported in units of $\mathrm{t} \cdot \mathrm{km}^{-2} \cdot \mathrm{y}^{-1}$ with appropriate conversion factors. The CWR of Cauvery river vary from 2 to $10.5 \mathrm{t} \cdot \mathrm{km}^{-2} \cdot \mathrm{y}^{-1}$ with a value of $2 \mathrm{t} \cdot \mathrm{km}^{-2} \cdot \mathrm{y}^{-1}$ at the outlet (Musiri) of the basin which is slightly higher than the previously reported values of 1.46 t. $\mathrm{km}^{-2} \cdot \mathrm{y}^{-1}$ by Pattanaik et al. ${ }^{14}$. The estimated CWR of $2 \mathrm{t} \cdot \mathrm{km}^{-2} \cdot \mathrm{y}^{-1}$ are several times lower than the corresponding SWR of $13 \mathrm{t} \cdot \mathrm{km}^{-2} \cdot \mathrm{y}^{-1}$, suggests the limited contribution of carbonate minerals to the dissolved load and dominant role of silicate weathering in CRB.

\section{2 $\mathrm{CO}_{2}$ consumption rates $(\mathrm{CCR})$ of $\mathrm{CRB}$}

The influence of rock/soil chemical weathering on atmospheric $\mathrm{CO}_{2}$ must be understood with respect to the time frame. Chemical weathering of silicate rocks is considered as a regulating factor of $\mathrm{CO}_{2}$ and hence the Earth's climate on long term ( $\left.>1 \mathrm{Myr}\right)$ evolution ${ }^{63}$, but on shorter time scales $(<1 \mathrm{kyr})$ chemical weathering of all lithologies are important for consumption of atmospheric $\mathrm{CO}_{2}$. However, it seems that silicate weathering $\mathrm{CO}_{2}$ consumption is highly sensitive to ongoing climatic variations ${ }^{64}$. The $\mathrm{CO}_{2}$ consumption rate (CCR) expressed in mole. $\mathrm{km}^{-2} \cdot \mathrm{y}^{-1}$ during the chemical weathering of silicate minerals depend on the cation flux derived and is calculated using the equation (19),

$\mathrm{CCR}=(\mathrm{Q} / \mathrm{A}) \cdot(\mathrm{Na}+\mathrm{K}+\mathrm{Mg}+\mathrm{Ca})_{\text {sil }}$

where $\mathrm{Q}$ is discharge in $\mathrm{m}^{3} \mathrm{~s}^{-1}, \mathrm{~A}$ is surface area of watershed in $\mathrm{km}^{2}$ and $(\mathrm{Na}+\mathrm{K}+\mathrm{Mg}+\mathrm{Ca})_{\mathrm{sil}}$ is the silicate weathering derived total cation concentration $(\mathrm{mol} / \mathrm{L})$ in the river water and the final values are reported in units of mole. $\mathrm{km}^{-2} \cdot \mathrm{y}^{-1}$ with appropriate conversion factors. The CCR of CRB vary from $3.3 \times 10^{5}$ to $7.4 \times 10^{5}$ mole. $\mathrm{km}^{-2} \cdot \mathrm{y}^{-1}$ with a value of $3.3 \times 10^{5}$ mole. $\mathrm{km}^{-2} \cdot \mathrm{y}^{-1}$ at the outlet (Musiri) of the basin which is almost comparable to the range $\left(3.2-3.8 \times 10^{5}\right)$ estimated by Pattanaik et al. ${ }^{14}$. Comparing the east and west flowing WG river systems, the average CCR of west flowing rivers $5.1 \times 10^{5}$ mole. $\mathrm{km}^{-2} \cdot \mathrm{y}^{-15,12}$ is slightly higher than the average 
1 CCR of the east flowing Cauvery river. Though the SWR of west flowing WG rivers are several

2 times ( 4) higher than the east flowing Cauvery river (section 5.1), the CCR values are

3 comparable for both river systems. This contrary behavior must be attributed to difference in

4 degree of weathering i.e., intense weathering $(\operatorname{Re} \sim 0)$ of west flowing WG rivers result in

5 relatively high $\mathrm{SiO}_{2}$ concentrations there by higher SWR than the moderate weathering $(\mathrm{Re} \sim$

63 ) of east flowing Cauvery river with relatively less $\mathrm{SiO}_{2}$ values. In addition, $\mathrm{CCR}$ of $\mathrm{CRB}$ is

7 slightly lower than the Peninsular river, Godavari $\left(5.8 \times 10^{5} \text { mole. } \mathrm{km}^{-2} \cdot \mathrm{y}^{-1}\right)^{65}$, while it is

8 comparable to the CCR of other Peninsular river, Krishna $\left(3.6 \times 10^{5} \text { mole. } \mathrm{km}^{-2} \cdot \mathrm{y}^{-1}\right)^{12}$. The CCR

9 of Himalayan river system such as Yamuna $\left(5 \times 10^{5} \text { mole. } \mathrm{km}^{-2} \cdot \mathrm{y}^{-1}\right)^{46}$, Bhagirathi-Alaknanda

$10\left(4 \times 10^{5} \text { mole. } \mathrm{km}^{-2} \cdot \mathrm{y}^{-1}\right)^{60}$, Ganga $\left(6.92 \times 10^{5} \text { mole. } \mathrm{km}^{-2} \cdot \mathrm{y}^{-1}\right)^{45}$ and Brahmaputra $\left(4.93 \times 10^{5}\right.$

11 mole. $\left.\mathrm{km}^{-2} \cdot \mathrm{y}^{-1}\right)^{45}$ are comparable to CRB while Indus $\left(0.6 \times 10^{5} \text { mole. } \mathrm{km}^{-2} \cdot \mathrm{y}^{-1}\right)^{60}$ has lower and Irrawady $\left(20 \times 10^{5} \text { mole. } \mathrm{km}^{-2} \cdot \mathrm{y}^{-1}\right)^{45}$ has higher CCR than the CRB. Further, comparing the CCR of Cauvery with world tropical rivers draining in cratonic/shield area such as the Amazon river $\left(0.5 \times 10^{5}\right.$ mole. $\left.\mathrm{km}^{-2} \cdot \mathrm{y}^{-1}\right)$, Orinoco river $\left(0.6 \times 10^{5}\right.$ mole. $\left.\mathrm{km}^{-2} \cdot \mathrm{y}^{-1}\right)$, Congo-Zaire $\left(0.5 \times 10^{5}\right.$ mole. $\left.\mathrm{km}^{-2} \cdot \mathrm{y}^{-1}\right)$ and Parana $\left(0.9 \times 10^{5}\right.$ mole. $\left.\mathrm{km}^{-2} \cdot \mathrm{y}^{-1}\right)$ found to have lower values ${ }^{45}$.

\section{Conclusions} understand the dissolved load sources, solute acquisition mechanisms and their controlling factors as well as to estimate the source-wise solute load, SWR and associated CCR. The salient findings of the study are:

(i) The dominant solute acquisition mechanism for CRB is chemical weathering i.e., waterrock/soil interaction with marginal influence of atmospheric processes at upstream followed by significantly increasing anthropogenic activities towards downstream. Out of the chemical weathering processes, silicate weathering is the major controlling mechanism for CRB with marginal influence from carbonate weathering. Source-wise contributions (discharge 
1 weighted) to the total dissolved load of CRB are estimated to be $13.5 \%, 18.5 \%, 59 \%$ and $9 \%$

2 from atmospheric input, anthropogenic activities, silicate and carbonate weathering

3 respectively by using the chemical mass balance model.

4 (ii) The intensity of silicate chemical weathering occurring in the CRB is indicated by the index

$5 \quad(\operatorname{Re})>3$ suggests less intense weathering of primary minerals and formation of soils consisting

6 of secondary minerals. Understanding of chemical weathering mechanisms occurring in the

$7 \quad$ CRB using the Na-normalized mixing of elemental ratios reveal that weathering of secondary

8 minerals from soils is influencing the dissolved load of CRB besides the primary rock minerals.

9 The solute load contribution from secondary minerals $(35.5 \%)$ is significantly higher than 10 primary minerals $(23.5 \%)$ to the dissolved load of CRB.

11 (iii) The computed SWR and CCR of CRB vary markedly along the river with values of 13 $12 \mathrm{t} \cdot \mathrm{km}^{-2} \cdot \mathrm{y}^{-1}$ and $3.3 \times 10^{5}$ mole. $\mathrm{km}^{-2} \cdot \mathrm{y}^{-1}$ respectively at the outlet (Musiri). The estimated SWR 13 of east flowing WG river, CRB $\left(13 \mathrm{t} \cdot \mathrm{km}^{-2} \cdot \mathrm{y}^{-1}\right)$ are several times $(\sim 4)$ lower than the average 14 SWR of west flowing WG rivers $\left(53 \mathrm{t} \cdot \mathrm{km}^{-2} \cdot \mathrm{y}^{-1}\right)$ even though the silicate weathering associated 15 CCR are comparable for both east flowing Cauvery $\left(3.3 \times 10^{5}\right.$ mole. $\left.\mathrm{km}^{-2} \cdot \mathrm{y}^{-1}\right)$ and west flowing $\left(5.1 \times 10^{5}\right.$ mole. $\left.\mathrm{km}^{-2} \cdot \mathrm{y}^{-1}\right) \mathrm{WG}$ rivers.

(iv) The contrary behavior of east and west flowing WG rivers might be, due to differences in degree of weathering intensity $(\mathrm{Re})$. $\mathrm{Re}>3$ for $\mathrm{CRB}$ indicating the bisiallitization phase of incomplete weathering resulting in formation of secondary minerals in the drainage basin with relatively less $\mathrm{SiO}_{2}$ and high cation fluxes to the river waters, whereas west flowing WG rivers have Re of 0.14 , suggesting the allitization phase of complete weathering in the drainage basin with relatively high silica and less cation fluxes to the river waters. 


\section{Data availability statement}

2 The data that support the findings of this study are available from the India-WRIS with the

3 following link https://indiawris.gov.in/wris/\#/waterData.

\section{Acknowledgements}

5 The authors sincerely thank Director, National Centre for Earth Science Studies (NCESS) for

6 the constant encouragement. Authors greatly acknowledge group head and deputy group head

7 of HyP Group, NCESS for their valuable support. Authors thankful to the data providers; CWC,

8 Ministry of Water Resources, Govt. of India.

\section{References}

1. Grosbois, C., Négrel, P., Fouillac, C. \& Grimaud, D. Dissolved load of the Loire River: chemical and isotopic characterization. Chemical Geology. 170(1-4), 179-201 (2000). https://doi.org/10.1016/S0009-2541(99)00247-8.

2. Braun, J.J., Descloitres, M., Riotte, J., Fleury, S., Barbiéro, L., Boeglin, J. L. \& Kumar, M.M. Regolith mass balance inferred from combined mineralogical, geochemical and geophysical studies: Mule Hole gneissic watershed, South India. Geochimica et Cosmochimica Acta. 73(4), 935-961 (2009). https://doi.org/10.1016/j.gca.2008.11.013.

3. Berner, R.A. \& Barron, E.J. Comments on the BLAG model; Factors affecting atmospheric $\mathrm{CO}_{2}$ and temperature over the past 100 million years. American Journal of Science. 284(10), 1183-1192 (1984). https://doi.org/10.2475/ajs.284.10.1183.

4. Brady, P.V. The effect of silicate weathering on global temperature and atmospheric $\mathrm{CO}_{2}$. Journal of Geophysical Research: Solid Earth. 96(B11), 18101-18106 (1991). https://doi.org/10.1029/91JB01898.

5. Gurumurthy, G.P., Balakrishna, K., Riotte, J., Braun, J.J., Audry, S., Shankar, H. U. \& Manjunatha, B.R. Controls on intense silicate weathering in a tropical river, southwestern India. Chemical Geology. 300, 61-69 (2012). https://doi.org/10.1016/j.chemgeo.2012.01.016.

6. Frondini, F., Vaselli, O. \& Vetuschi Zuccolini, M. Consumption of Atmospheric Carbon Dioxide through Weathering of Ultramafic Rocks in the Voltri Massif (Italy): Quantification of the Process and Global Implications. Geosciences. 9(6), 258 (2019). https://doi.org/10.3390/geosciences9060258.

7. Sarin, M.M., Krishnaswami, S., Dilli, K., Somayajulu, B.L.K. \& Moore, W.S. Major ion chemistry of the Ganga-Brahmaputra river system: Weathering processes and fluxes to the Bay of Bengal. Geochimica et cosmochimica acta. 53(5), 997-1009 (1989). https://doi.org/10.1016/0016-7037(89)90205-6. 
8. Pande, K., Sarin, M.M., Trivedi, J.R., Krishnaswami, S., \& Sharma, K.K. The Indus river system (India-Pakistan): Major-ion chemistry, uranium and strontium isotopes. Chemical Geology. 116(3-4), 245-259 (1994). https://doi.org/10.1016/0009-2541(94)90017-5.

9. Galy, A. \& France-Lanord, C. Weathering processes in the Ganges-Brahmaputra basin and the riverine alkalinity budget. Chemical Geology. 159(1-4), 31-60 (1999). https://doi.org/10.1016/S0009-2541(99)00033-9.

10. Singh, A.K., Mondal, G.C., Singh, P.K., Singh, S., Singh, T.B. \& Tewary, B.K. Hydrochemistry of reservoirs of Damodar River basin, India: weathering processes and water quality assessment. Environmental Geology. 48(8), 1014-1028 (2005). https://doi.org/10.1007/s00254-005-1302-6.

11. Dessert, C., Dupré, B., François, L. M., Schott, J., Gaillardet, J., Chakrapani, G. \& Bajpai, S. Erosion of Deccan Traps determined by river geochemistry: impact on the global climate and the 87Sr/86Sr ratio of seawater. Earth and Planetary Science Letters. 188(3-4), 459474 (2001). https://doi.org/10.1016/S0012-821X(01)00317-X.

12. Das, A., Krishnaswami, S., Sarin, M.M. \& Pande, K. Chemical weathering in the Krishna Basin and Western Ghats of the Deccan Traps, India: Rates of basalt weathering and their controls. Geochimica et Cosmochimica Acta. 69(8), 2067-2084 (2005). https://doi.org/10.1016/j.gca.2004.10.014.

13. Gupta, H., Chakrapani, G.J., Selvaraj, K. \& Kao, S.J. The fluvial geochemistry, contributions of silicate, carbonate and saline-alkaline components to chemical weathering flux and controlling parameters: Narmada River (Deccan Traps), India. Geochimica et Cosmochimica Acta. 75(3), 800-824 (2011). https://doi.org/10.1016/j.gca.2010.11.010.

14. Pattanaik, J.K., Balakrishnan, S., Bhutani, R. \& Singh, P. Estimation of weathering rates and $\mathrm{CO} 2$ drawdown based on solute load: Significance of granulites and gneisses dominated weathering in the Kaveri River basin, Southern India. Geochimica et Cosmochimica Acta. 121, 611-636 (2013). https://doi.org/10.1016/j.gca.2013.08.002.

15. Thomas, J., Joseph, S., \& Thrivikramji, K.P. Hydrochemical variations of a tropical mountain river system in a rain shadow region of the southern Western Ghats, Kerala, India. Applied Geochemistry. 63, 456-471 (2015). https://doi.org/10.1016/j.apgeochem.2015.03.018.

16. Violette, A., Godderis, Y., Maréchal, J.C., Riotte, J., Oliva, P., Kumar, M.M. \& Braun, J.J. Modelling the chemical weathering fluxes at the watershed scale in the Tropics (Mule Hole, South India): Relative contribution of the smectite/kaolinite assemblage versus primary minerals. Chemical Geology. 277(1-2), 42-60 (2010a). http://doi.org/10.1016/j.chemgeo.2010.07.009.

17. Gurumurthy, G.P., Balakrishna, K., Tripti, M., Riotte, J., Audry, S., Braun, J.J., \& Shankar, H.U. Use of $\mathrm{Sr}$ isotopes as a tool to decipher the soil weathering processes in a tropical river catchment, southwestern India. Applied Geochemistry. 63, 498-506 (2015). https://doi.org/10.1016/j.apgeochem.2015.03.005.

18. Sharma, A. \& Rajamani, V. Weathering of gneissic rocks in the upper reaches of Cauvery river, south India: implications to neotectonics of the region. Chemical Geology. 166(3-4), 203-223 (2000). https://doi.org/10.1016/S0009-2541(99)00222-3. 
19. Rajamani, V., Tripathi, J.K. \& Malviya, V.P. Weathering of lower crustal rocks in the Kaveri river catchment, southern India: implications to sediment geochemistry. Chemical Geology. 265(3-4), 410-419 (2009). https://doi.org/10.1016/j.chemgeo.2009.05.007.

20. Geetha Selvarani, A. and Elangovan, K. Hydrogeochemistry Analysis of Groundwater in Noyyal River Basin, Tamilnadu, India. International Journal of Applied Environmental Sciences. 4( 2), 211-227, (2009).

21. Ahamed, A. J., Loganathan, K., \& Jayakumar, R. Hydrochemical characteristics and quality assessment of groundwater in Amaravathi river basin of Karur district, Tamil Nadu, South India. Sustainable Water Resources Management, 1(3), 273-29 (2015).

22. Hema,S \& Subramani,T. Water Quality Index of Cauvery River and its Three Tributaries, South India. Asian Journal of Research in Social Sciences and Humanities. 6 (10), 761 769, (2016).

23. Pattanaik, J.K., Balakrishnan, S., Bhutani, R. \& Singh, P. Chemical and strontium isotopic composition of Kaveri, Palar and Ponnaiyar rivers: significance to weathering of granulites and granitic gneisses of southern Peninsular India. Current Science. 93(4), 523-531 (2007).

24. Cauvery basin report, Ministry of water resources, Government of India, 2014.

25. Sushant, S., Balasubramani, K. \& Kumaraswamy, K. Spatio-temporal analysis of rainfall distribution and variability in the twentieth century, over the Cauvery Basin, South India. Environmental Management of River Basin Ecosystems. 21-41 (2015). https://doi.org/10.1007/978-3-319-13425-3_2.

26. Bhuvaneswari, K., Geethalakshmi, V., Lakshmanan, A., Srinivasan, R. \& Sekhar, N.U. The impact of El Nino/Southern oscillation on hydrology and Rice productivity in the Cauvery Basin, India: Application of the soil and water assessment tool. Weather and Climate Extremes. 2, 39-47 (2013). https://doi.org/10.1016/j.wace.2013.10.003.

27. Durand, N., Gunnell, Y., Curmi, P. \& Ahmad, S.M. Pathways of calcrete development on weathered silicate rocks in Tamil Nadu, India: Mineralogy, chemistry and paleoenvironmental implications. Sedimentary Geology. 192(1-2), 1-18 (2006). https://doi.org/10.1016/j.sedgeo.2006.03.020.

28. Violette, A., Riotte, J., Braun, J.J., Oliva, P., Marechal, J.C., Sekhar, M. \& Dupre, B. Formation and preservation of pedogenic carbonates in South India, links with paleomonsoon and pedological conditions: Clues from $\mathrm{Sr}$ isotopes, U-Th series and REEs. Geochimica et Cosmochimica Acta. 74(24), 7059-7085 (2010b). https://doi.org/10.1016/j.gca.2010.09.006.

29. Sastri, V.V., Raju, A.T. R., Sinha, R.N., Venkatachala, B.S. \& Banerji, R.K. Biostratigraphy and evolution of the Cauvery Basin, India. Geological Society of India. 18(8), 355-377 (1977).

30. Sekar, R. \& Palanichamy, P.A. Land suitability for major crops in Cauvery Basin, Tamil $\mathrm{Nadu}$, India using remote sensing and GIS techniques. International Journal of Research in Applied, Natural and Social Sciences. 4, 9-24 (2016).

31. Tripathi, J. K., \& Rajamani, V. Geochemistry and origin of ferruginous nodules in weathered granodioritic gneisses, Mysore Plateau, Southern India. Geochimica et Cosmochimica Acta. 71(7), 1674-1688 (2007). https://doi.org/10.1016/j.gca.2007.01.001.

32. Pandit, M.K., Kumar, M., Sial, A.N., Sukumaran, G.B., Piementle, M. \& Ferreira, V.P. Geochemistry and $\mathrm{C}-\mathrm{O}$ and $\mathrm{Nd}-\mathrm{Sr}$ isotope characteristics of the $2.4 \mathrm{Ga}$ Hogenakkal 
carbonatites from the South Indian Granulite Terrane: evidence for an end-Archaean depleted component and mantle heterogeneity. International Geology Review. 58(12), 1461-1480 (2016). https://doi.org/10.1080/00206814.2016.1163646.

33. Madhavaraju, J. Geochemistry of late cretaceous sedimentary rocks of the Cauvery Basin, South India: constraints on paleo weathering, provenance, and end cretaceous environments. Chemostratigraphy. 185-214 (2015). https://doi.org/10.1016/B978-0-12419968-2.00008-X.

34. Integrated hydrological data book (non-classified river basins), New Delhi, Hydrological data directorate information systems organization water planning \& projects wing central water commission (2012).

35. Paudyal, R., Kang, S., Sharma, C.M., Tripathee, L., Huang, J., Rupakheti, D. \& Sillanpää, M. Major ions and trace elements of two selected rivers near Everest region, southern Himalayas, Nepal. Environmental Earth Sciences. 75(1), $46 \quad$ (2016). https://doi.org/10.1007/s12665-015-4811-y.

36. Berner, E. K. \& Berner, R.A. Global Environment: Water, Air and Geochemical Cycles. Prentice-Hall, Upper Saddle River. 1, 30 -370 (1996).

37. Chen, J., Wang, F., Xia, X., \& Zhang, L. Major element chemistry of the Changjiang (Yangtze River). Chemical Geology. 187(3-4), 231-255 (2002). https://doi.org/10.1016/S0009-2541(02)00032-3.

38. Gibbs, R.J. Mechanisms controlling world water chemistry. Science. 170(3962), 10881090 (1970). https://doi.org/10.1126/science.170.3962.1088.

39. Tardy, Y. Characterization of the principal weathering types by the geochemistry of waters from some European and African crystalline massifs. Chemical Geology. 7(4), 253-271 (1971). https://doi.org/10.1016/0009-2541(71)90011-8.

40. Boeglin, J.L. \& Probst, J.L. Physical and chemical weathering rates and $\mathrm{CO}_{2}$ consumption in a tropical lateritic environment: the upper Niger basin. Chemical geology. 48(3-4), 137156 (1998). https://doi.org/10.1016/S0009-2541(98)00025-4.

41. Rao, Y.B., Sivaraman, T.V., Pantulu, G.V.C., Gopalan, K. \& Naqvi, S.M. Rb-Sr ages of late Archean metavolcanics and granites, Dharwar Craton, South India and evidence for early Proterozoic thermotectonic event (s). Precambrian Research. 59(1-2), 145-170 (1992). https://doi.org/10.1016/0301-9268(92)90055-S.

42. Jayananda, M., Moyen, J.F., Martin, H., Peucat, J.J., Auvray, B. \& Mahabaleswar, B. Late Archaean (2550-2520 Ma) juvenile magmatism in the Eastern Dharwar craton, southern India: constraints from geochronology, $\mathrm{Nd}-\mathrm{Sr}$ isotopes and whole rock geochemistry. Precambrian Research, 99(3-4), 225-254 (2000). https://doi.org/10.1016/S0301-9268(99)00063-7.

43. Tomson, J.K., Rao, Y.B., Kumar, T.V. \& Rao, J.M. Charnockite genesis across the Archaean-Proterozoic terrane boundary in the South Indian Granulite Terrain: Constraints from major-trace element geochemistry and $\mathrm{Sr}-\mathrm{Nd}$ isotopic systematics. Gondwana Research. 10(1-2), 115-127 (2006). https://doi.org/10.1016/j.gr.2005.11.023.

44. Hagedorn, B. \& Whittier, R.B. Solute sources and water mixing in a flashy mountainous stream (Pahsimeroi River, US Rocky Mountains): Implications on chemical weathering rate and groundwater-surface water interaction. Chemical Geology. 391, 123-137 (2015). https://doi.org/10.1016/j.chemgeo.2014.10.031. 
45. Gaillardet, J., Dupré, B., Louvat, P. \& Allegre, C. J. Global silicate weathering and $\mathrm{CO}_{2}$ consumption rates deduced from the chemistry of large rivers. Chemical geology. 159(14), 3-30 (2015). https://doi.org/10.1016/S0009-2541(99)00031-5.

46. Dalai, T.K., Krishnaswami, S. \& Sarin, M.M. Major ion chemistry in the headwaters of the Yamuna river system: Chemical weathering, its temperature dependence and $\mathrm{CO}_{2}$ consumption in the Himalaya. Geochimica et Cosmochimica Acta. 66(19), 3397-3416 (2002). https://doi.org/10.1016/S0016-7037(02)00937-7.

47. Moon, S., Huh, Y., Qin, J. \& van Pho, N. Chemical weathering in the Hong (Red) River basin: rates of silicate weathering and their controlling factors. Geochimica et Cosmochimica Acta. 71(6), 1411-1430 (2007). https://doi.org/10.1016/j.gca.2006.12.004.

48. Wu, W., Xu, S., Yang, J., \& Yin, H. Silicate weathering and $\mathrm{CO}_{2}$ consumption deduced from the seven Chinese rivers originating in the Qinghai-Tibet Plateau. Chemical Geology, 249(3-4), 307-320 (2008). https://doi.org/10.1016/j.chemgeo.2008.01.025.

49. Meybeck, M. Atmospheric inputs and river transport of dissolved substances. Dissolved loads of rivers and surface water quantity/quality relationships. IAHS Publ. 141, 173-192 (1983).

50. Zade, M., Ray, S.S., Dutta, S. \& Panigrahy, S. Analysis of runoff pattern for all major basins of India derived using remote sensing data. Current science, 1301-1305 (2005).

51. Rai, S.K., Singh, S.K. \& Krishnaswami, S. Chemical weathering in the plain and peninsular sub-basins of the Ganga: impact on major ion chemistry and elemental fluxes. Geochimica et Cosmochimica Acta. 74(8), 2340-2355, (2010). https://doi.org/10.1016/j.gca.2010.01.008.

52. Xu, Z., Shi, C., Tang, Y., \& Han, H. Chemical and strontium isotopic compositions of the Hanjiang Basin Rivers in China: anthropogenic impacts and chemical weathering. Aquatic Geochemistry. 17(3), 243-264 (2011). https://doi.org/10.1007/s10498-011-9132-5.

53. Krishnaswami, S. \& Singh, S.K. Chemical weathering in the river basins of the Himalaya, India. Current science. 89(5), 841-849 (2005).

54. Xiao, J., Jin, Z. D., Ding, H., Wang, J., \& Zhang, F. Geochemistry and solute sources of surface waters of the Tarim River Basin in the extreme arid region, NW Tibetan Plateau. Journal of Asian Earth Sciences. 54, 162-173 (2012). https://doi.org/10.1016/j.jseaes.2012.04.009.

55. Moldan, B. \& Cerny, J. Biogeochemistry of small catchments: a tool for environmental research (No. 551.48 B615). John Wiley \& Sons. (1994).

56. Yoo, K. \& Mudd, S.M. Discrepancy between mineral residence time and soil age: Implications for the interpretation of chemical weathering rates. Geology. 36(1), 35-38 (2008). https://doi.org/10.1130/G24285A.1.

57. Walker, J.C., Hays, P.B. \& Kasting, J.F. A negative feedback mechanism for the longterm stabilization of Earth's surface temperature. Journal of Geophysical Research: Oceans. 86(C10), 9776-9782 (1981). https://doi.org/10.1029/JC086iC10p09776.

58. Moore, J., Jacobson, A.D., Holmden, C. \& Craw, D. Tracking the relationship between mountain uplift, silicate weathering, and long-term $\mathrm{CO}_{2}$ consumption with $\mathrm{Ca}$ isotopes: Southern Alps, New Zealand. Chemical Geology. 341, 110-127 (2013). https://doi.org/10.1016/j.chemgeo.2013.01.005. 
59. Viers, J., Dupré, B., Braun, J.J., Deberdt, S., Angeletti, B., Ngoupayou, J.N. \& Michard, A. Major and trace element abundances, and strontium isotopes in the Nyong basin rivers (Cameroon): constraints on chemical weathering processes and elements transport mechanisms in humid tropical environments. Chemical Geology. 169(1-2), 211-241 (2000). https://doi.org/10.1016/S0009-2541(00)00298-9.

60. Krishnaswami, S. \& Singh, S.K. Silicate and carbonate weathering in the drainage basins of the Ganga-Ghaghara-Indus head waters: Contributions to major ion and $\mathrm{Sr}$ isotope geochemistry. Proc. Indian Acad. Sci. (Earth Planet Sci.). 107: 283-291 (1998). https://doi.org/10.1007/BF02841595.

61. West, A.J., Galy, A. \& Bickle, M. Tectonic and climatic controls on silicate weathering. Earth and Planetary Science Letters. 235(1-2), 211-228 (2005). https://doi.org/10.1016/j.epsl.2005.03.020.

62. Braun, J.J., Ngoupayou, J.R.N., Viers, J., Dupre, B., Bedimo, J.P.B., Boeglin, J.L. \& Rouiller, J. Present weathering rates in a humid tropical watershed: Nsimi, South Cameroon. Geochimica et Cosmochimica Acta. 69(2), 357-387 (2005). https://doi.org/10.1016/j.gca.2004.06.022.

63. Sundquist, E.T. Steady-and non-steady-state carbonate-silicate controls on atmospheric $\mathrm{CO}_{2}$. Quaternary Science Reviews. 10(2-3), 283-296 (1991). https://doi.org/10.1016/02773791(91)90026-Q.

64. Gislason, S.R., Oelkers, E.H., Eiriksdottir, E.S., Kardjilov, M.I., Gisladottir, G., Sigfusson, B. \& Oskarsson, N. Direct evidence of the feedback between climate and weathering. Earth and Planetary Science Letters. 277(1-2), 213-222 (2009). https://doi.org/10.1016/j.epsl.2008.10.018.

65. Jha, P.K., Tiwari, J., Singh, U.K., Kumar, M. \& Subramanian, V. Chemical weathering and associated $\mathrm{CO}_{2}$ consumption in the Godavari river basin, India. Chemical Geology. 264(14), 364-374 (2009. https://doi.org/10.1016/j.chemgeo.2009.03.025.

\section{Author Contributions}

B.U and M.C contributed to design of the study, data preparation and manuscript writing. A.A, V.V.D and G.S contributed in preparation of Maps, Figures and Tables. K.A.K contributed in conceiving the ideas and reviewing the manuscript.

\section{Additional Information}

Competing Interests: The authors declare no competing interests. 


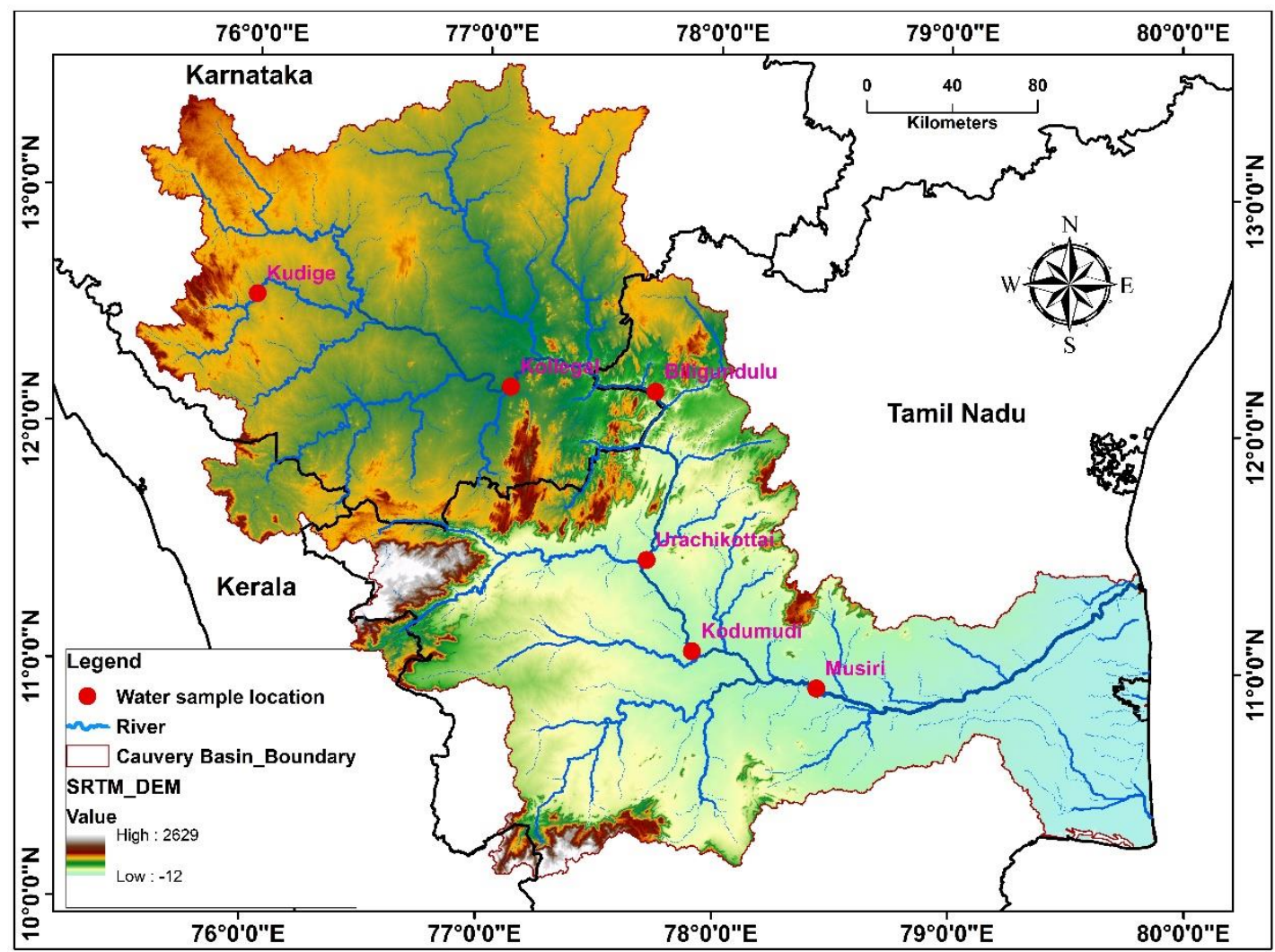

3

4 Figure 1. Cauvery River Basin (CRB) with drainage network, elevation and hydrological 5 observatory $(\mathrm{HO})$ stations;

6 

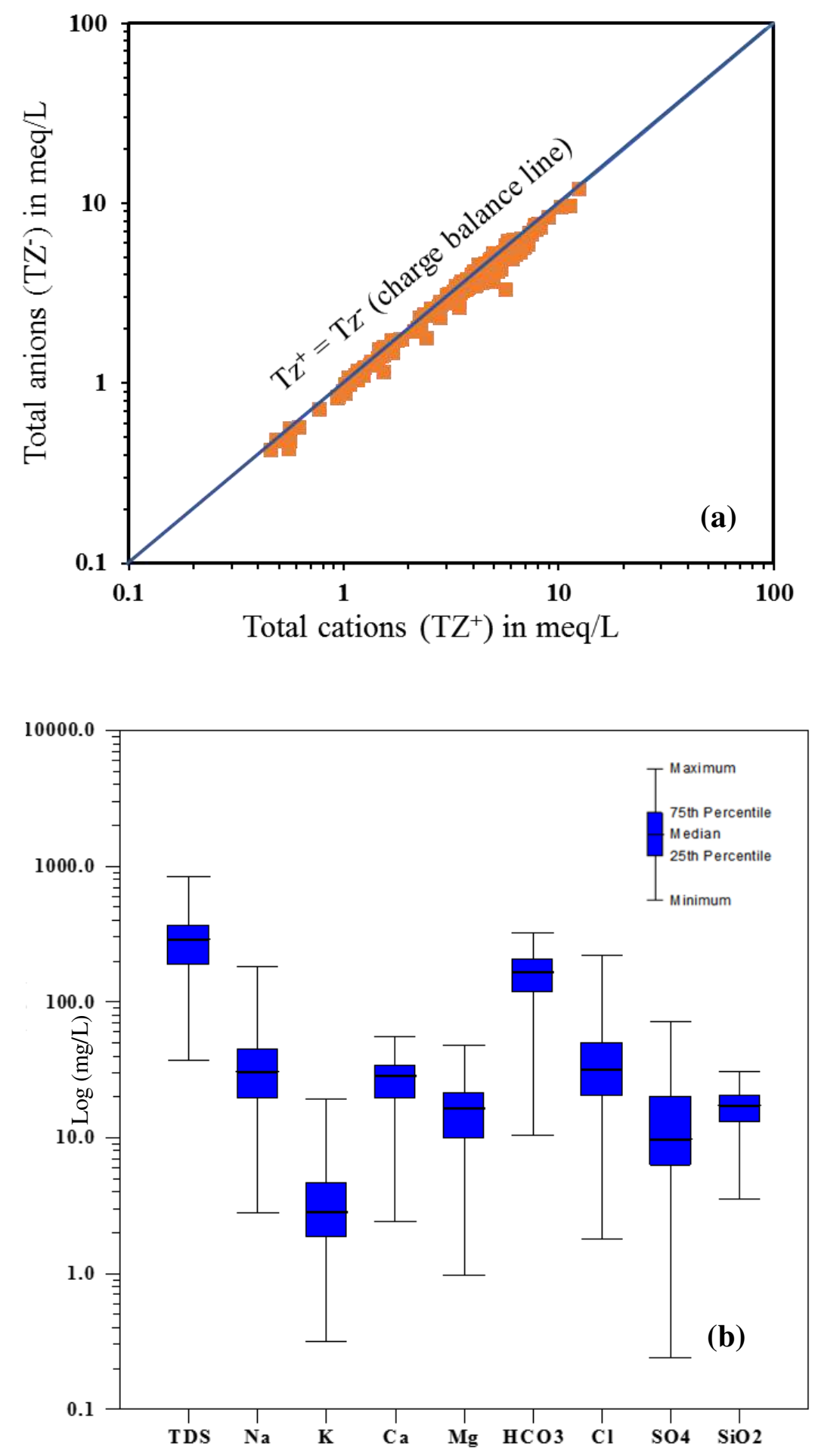

27

Figure 2. (a) Scatter plot between total cations (meq/L) and total anions (meq/L), indicating by and large the cations and anions are balanced, (b) Box plot of physio-chemical parameters, showing variation in the hydrochemical data of CRB. 
Figure 3. (a) Gibbs plot for CRB, specifying the overall dominance of water-rock/soil interaction over the hydrochemistry, though the data points are not clustered rather range
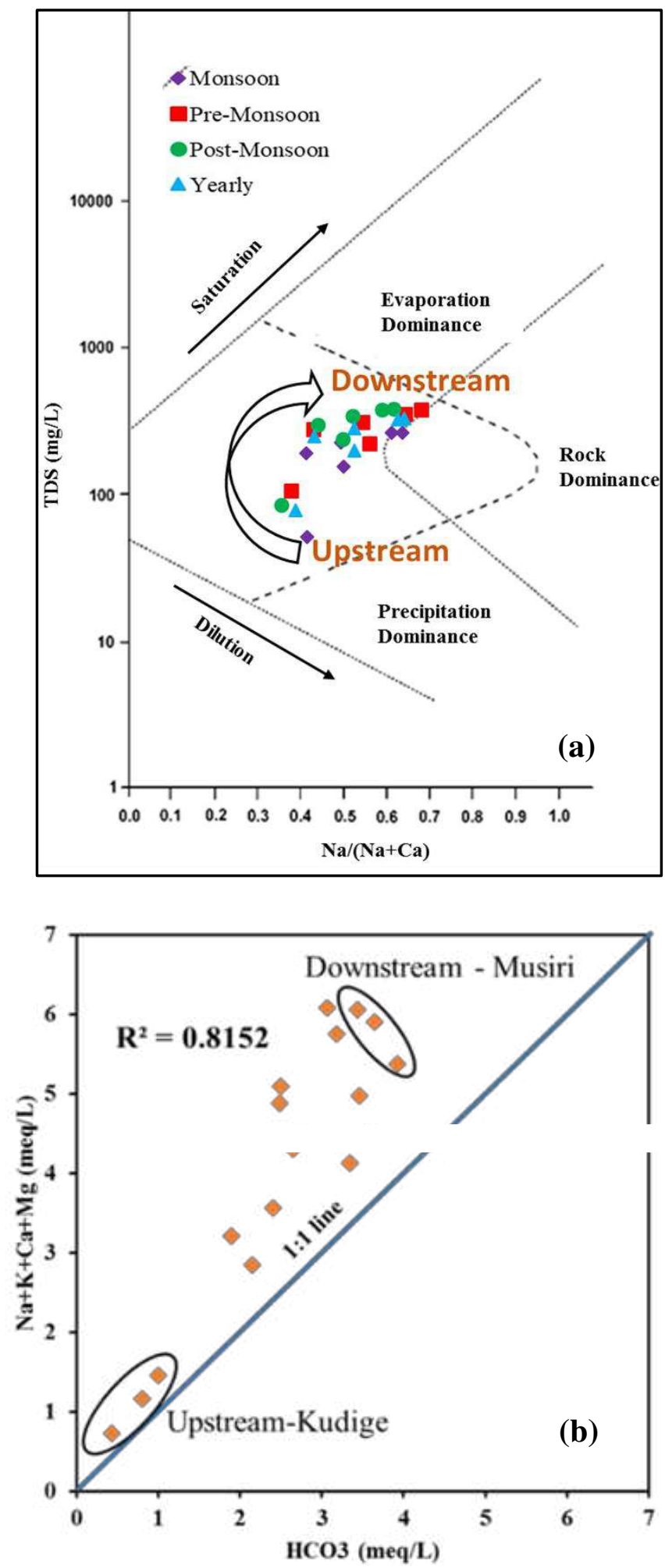

(1)

$$
\text { from one end to other, (b) Scatter plot of } \mathrm{HCO}_{3} \mathrm{vs} \mathrm{Na}+\mathrm{K}+\mathrm{Ca}+\mathrm{Mg} \text { with } \mathrm{R}^{2}=0.81 \text {, suggesting }
$$
the common mechanism for all these ions i.e., chemical weathering of drainage minerals. 

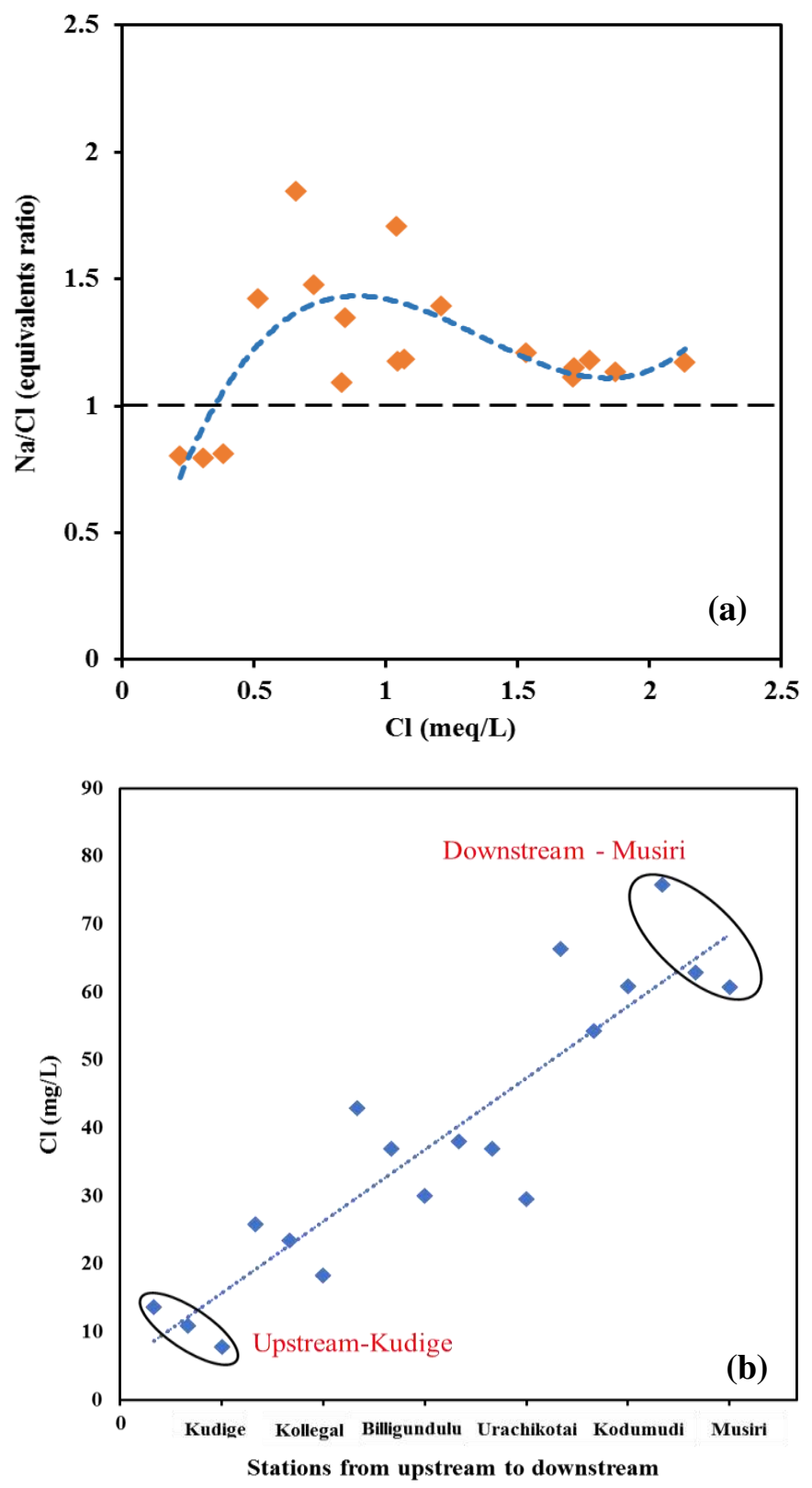

Figure 4. (a) Variation of chloride $(\mathrm{Cl})$ concentration from upstream to downstream, (b) Scatter plot of $\mathrm{Cl}$ vs $\mathrm{Na} / \mathrm{Cl}$, indicating the addition of $\mathrm{Na}$ up to middle reaches due to the silicate weathering, then addition of both $\mathrm{Na}$ and $\mathrm{Cl}$ towards the downstream due the anthropogenic inputs 


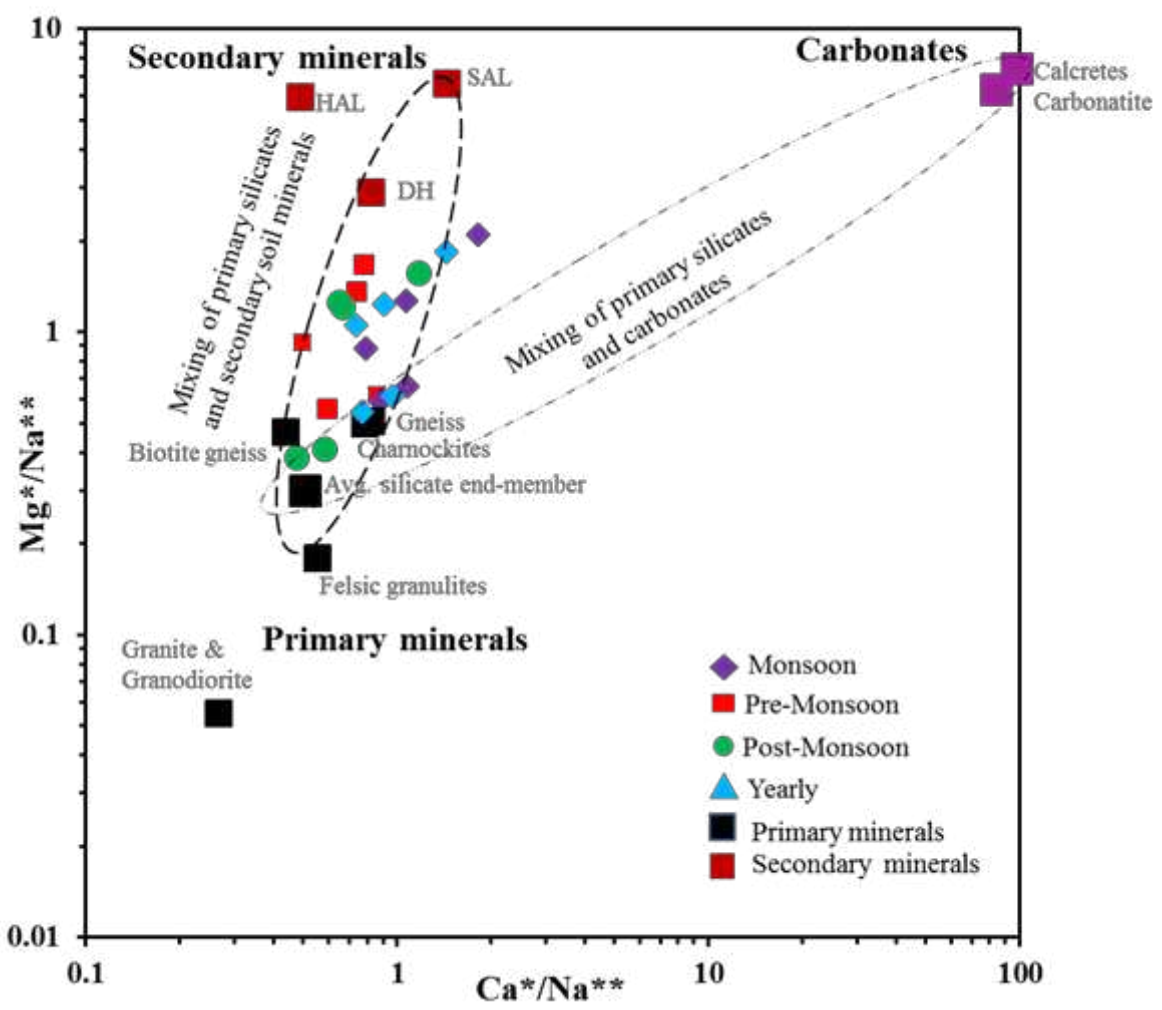

Figure 5. End-member mixing diagram for ' 3 ' different end-members in terms of $\mathrm{Ca} / \mathrm{Na}$ and $\mathrm{Mg} / \mathrm{Na}$ ratios for $\mathrm{CRB}$; primary silicate minerals from rocks, secondary silicate minerals in soils and sparsely available carbonate minerals, describing a mixing trend between primary minerals and secondary minerals for CRB water samples. 
Figure 6. Source-wise solute load contributions (discharge weighted) to the total dissolved load of CRB from (a) atmospheric input, carbonate, silicate weathering and anthropogenic sources (b) atmospheric input, carbonate, secondary minerals, primary minerals weathering and anthropogenic sources, solute load of secondary minerals weathering $(35.5 \%)$ is significantly higher than the primary minerals (23.5\%), emphasizing the role of secondary soil minerals control over the CRB hydrochemistry. 


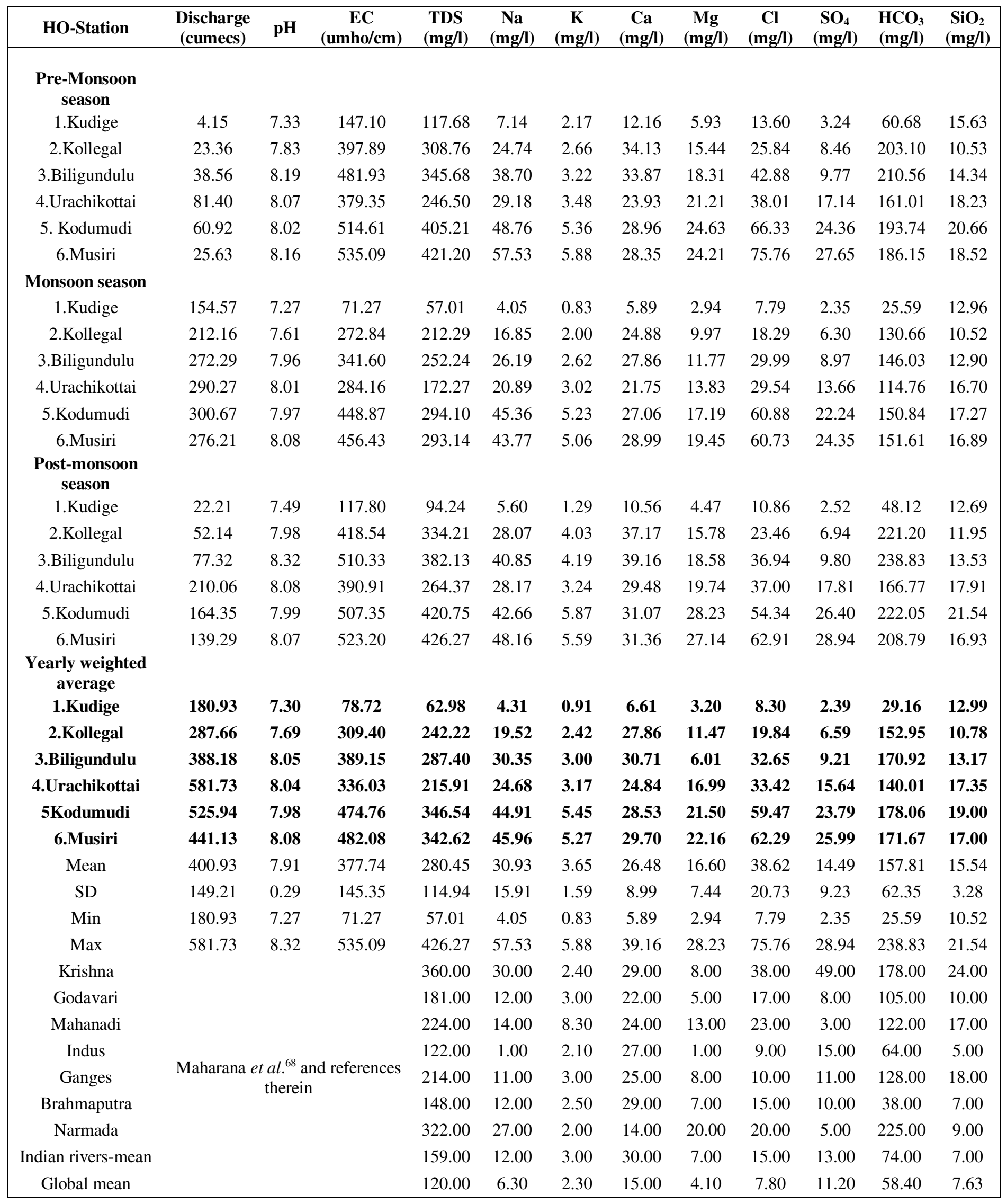

1

2 Table 1. Surface water physio-chemical composition of Cauvery river \& comparison with other rivers. 


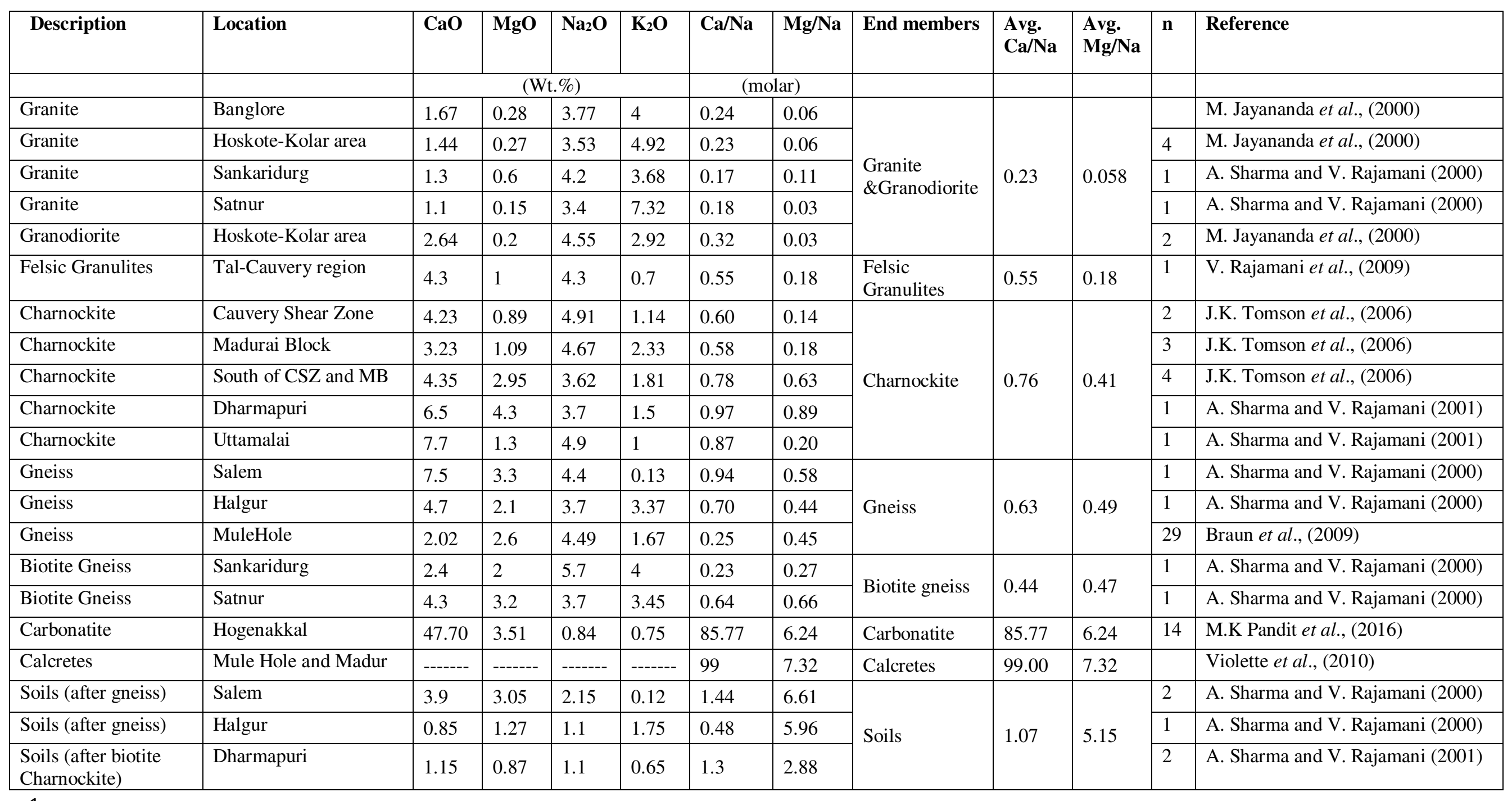

1

2 Table 2. Molar ratios of $\mathrm{Ca} / \mathrm{Na}$ and $\mathrm{Mg} / \mathrm{Na}$ values estimated for different dominant end-members using various rock types and soil (weathered)

3 profiles present in CRB 
Figures

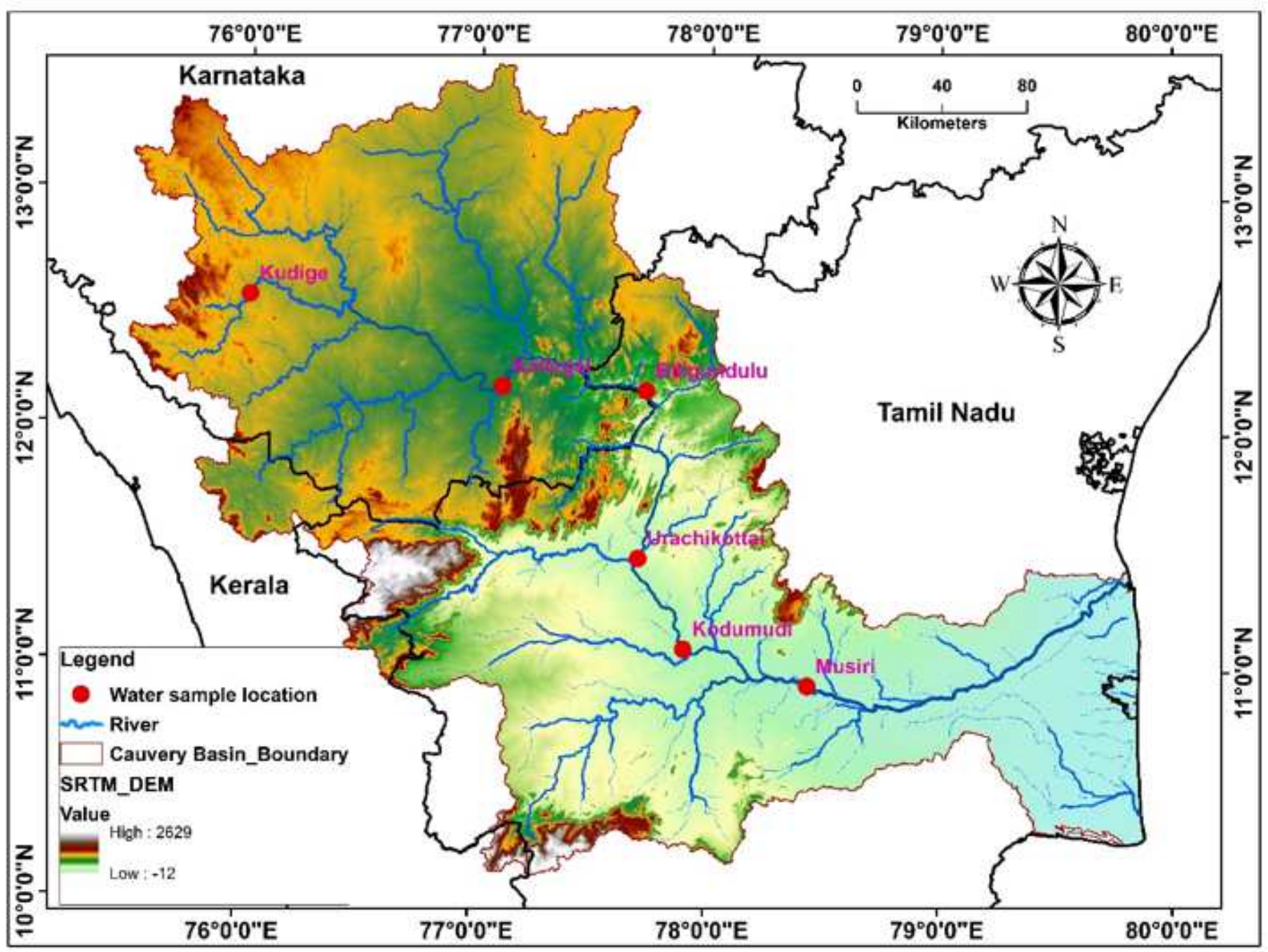

Figure 1

Cauvery River Basin (CRB) with drainage network, elevation and hydrological observatory (HO) stations; Note: The designations employed and the presentation of the material on this map do not imply the expression of any opinion whatsoever on the part of Research Square concerning the legal status of any country, territory, city or area or of its authorities, or concerning the delimitation of its frontiers or boundaries. This map has been provided by the authors. 

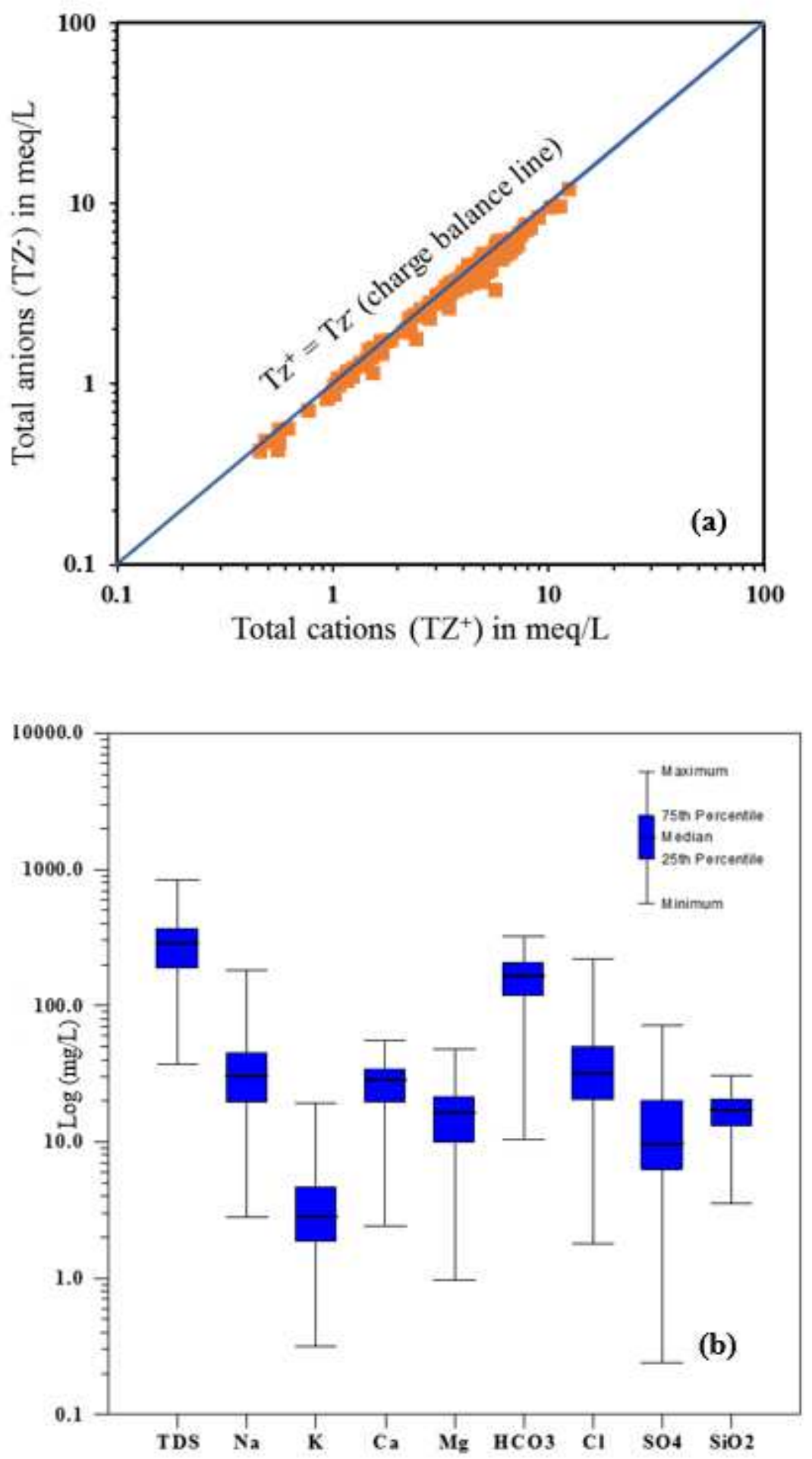

Figure 2

(a) Scatter plot between total cations (meq/L) and total anions (meq/L), indicating by and large the cations and anions are balanced, (b) Box plot of physio-chemical parameters, showing variation in the hydrochemical data of CRB. 

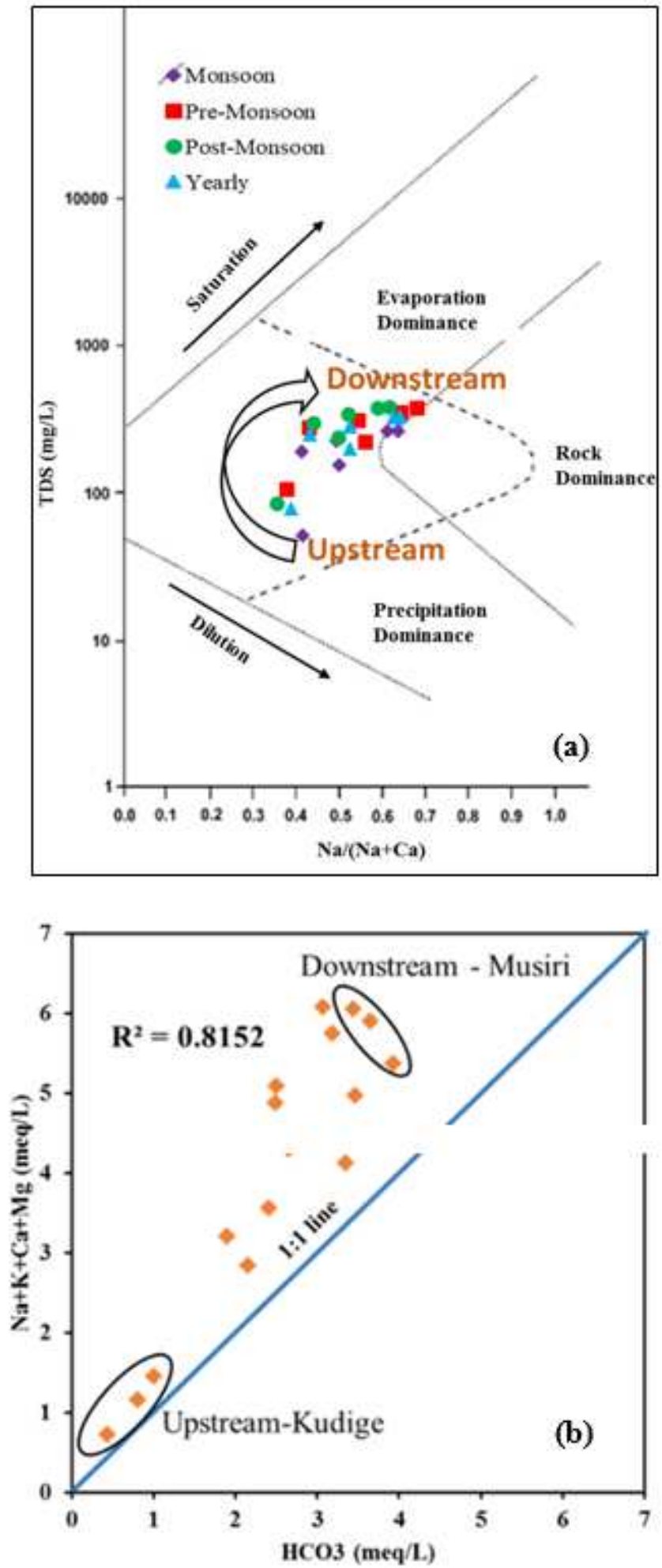

Figure 3

(a) Gibbs plot for CRB, specifying the overall dominance of water-rock/soil interaction over the hydrochemistry, though the data points are not clustered rather range from one end to other, (b) Scatter plot of $\mathrm{HCO} 3$ vs $\mathrm{Na}+\mathrm{K}+\mathrm{Ca}+\mathrm{Mg}$ with $\mathrm{R} 2=0.81$, suggesting the common mechanism for all these ions i.e., chemical weathering of drainage minerals. 

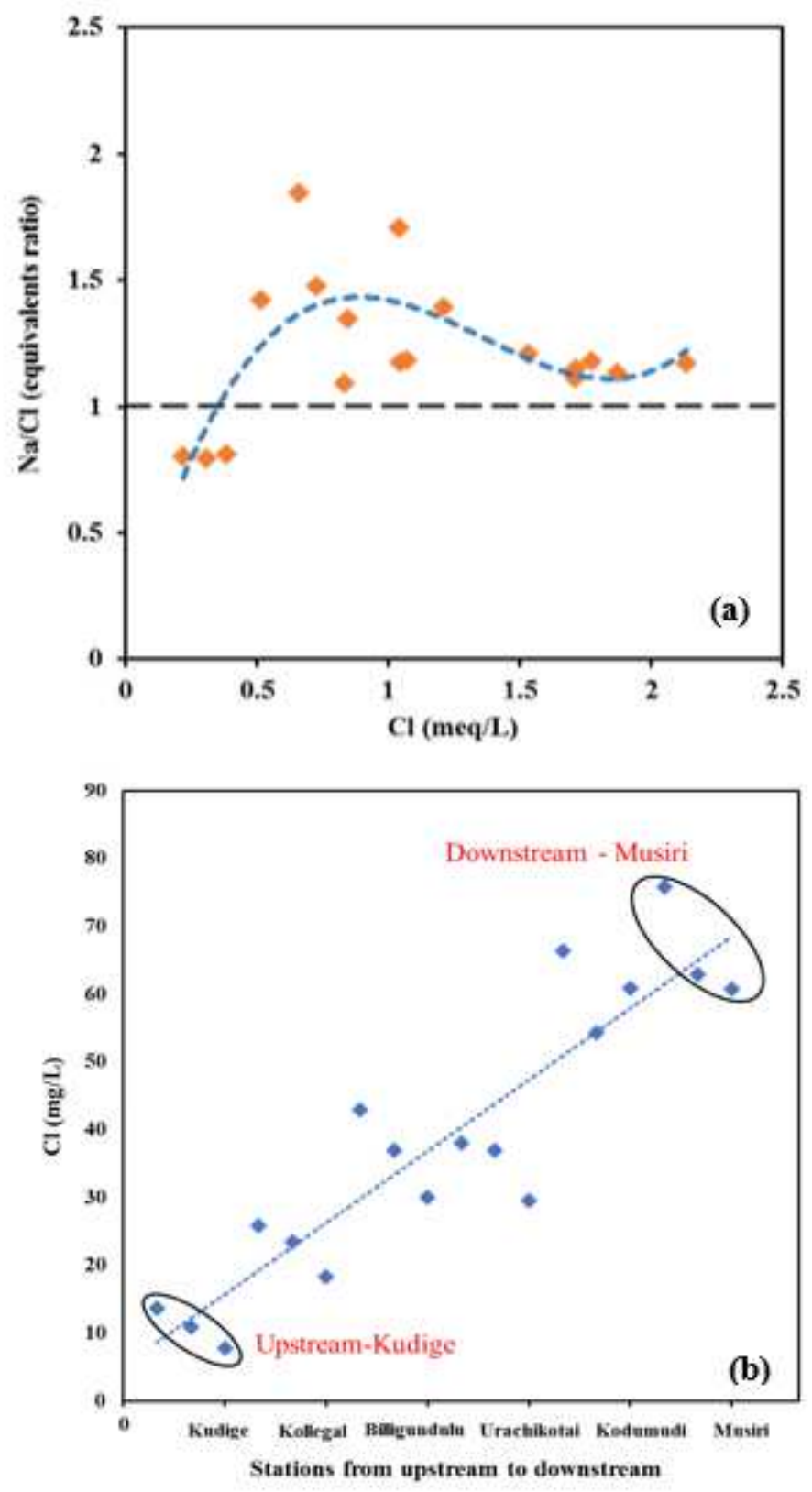

Figure 4

(a) Variation of chloride (Cl) concentration from upstream to downstream, (b) Scatter plot of $\mathrm{Cl} v \mathrm{Na} / \mathrm{Cl}$, indicating the addition of $\mathrm{Na}$ up to middle reaches due to the silicate weathering, then addition of both $\mathrm{Na}$ and $\mathrm{Cl}$ towards the downstream due the anthropogenic inputs 


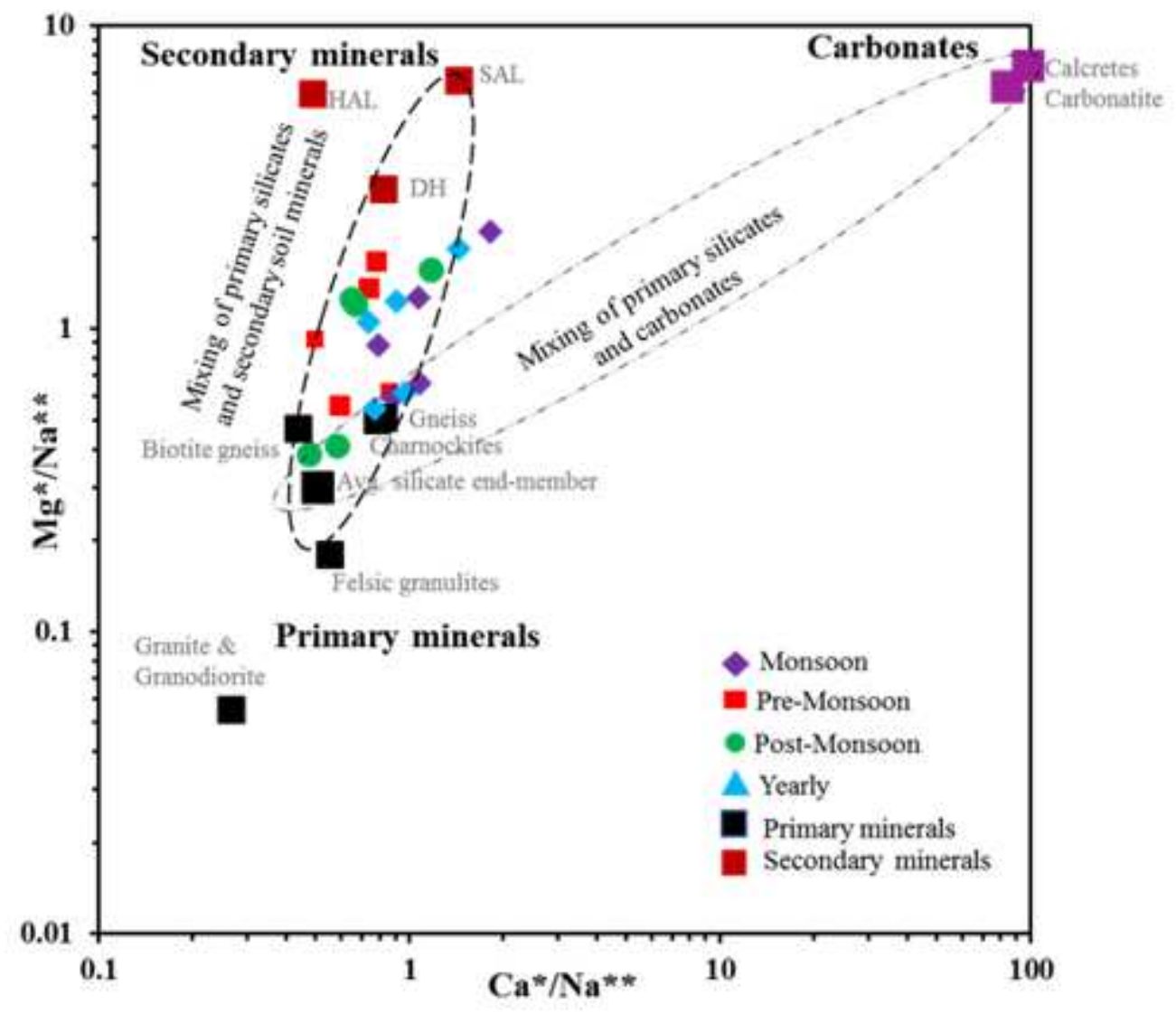

Figure 5

End-member mixing diagram for ' 3 ' different end-members in terms of $\mathrm{Ca} / \mathrm{Na}$ and $\mathrm{Mg} / \mathrm{Na}$ ratios for $\mathrm{CRB}$; primary silicate minerals from rocks, secondary silicate minerals in soils and sparsely available carbonate minerals, describing a mixing trend between primary minerals and secondary minerals for CRB water samples. *HAL, SAL and DH refer to soil samples from Halgur, Salem and Dharmapuri respectively 

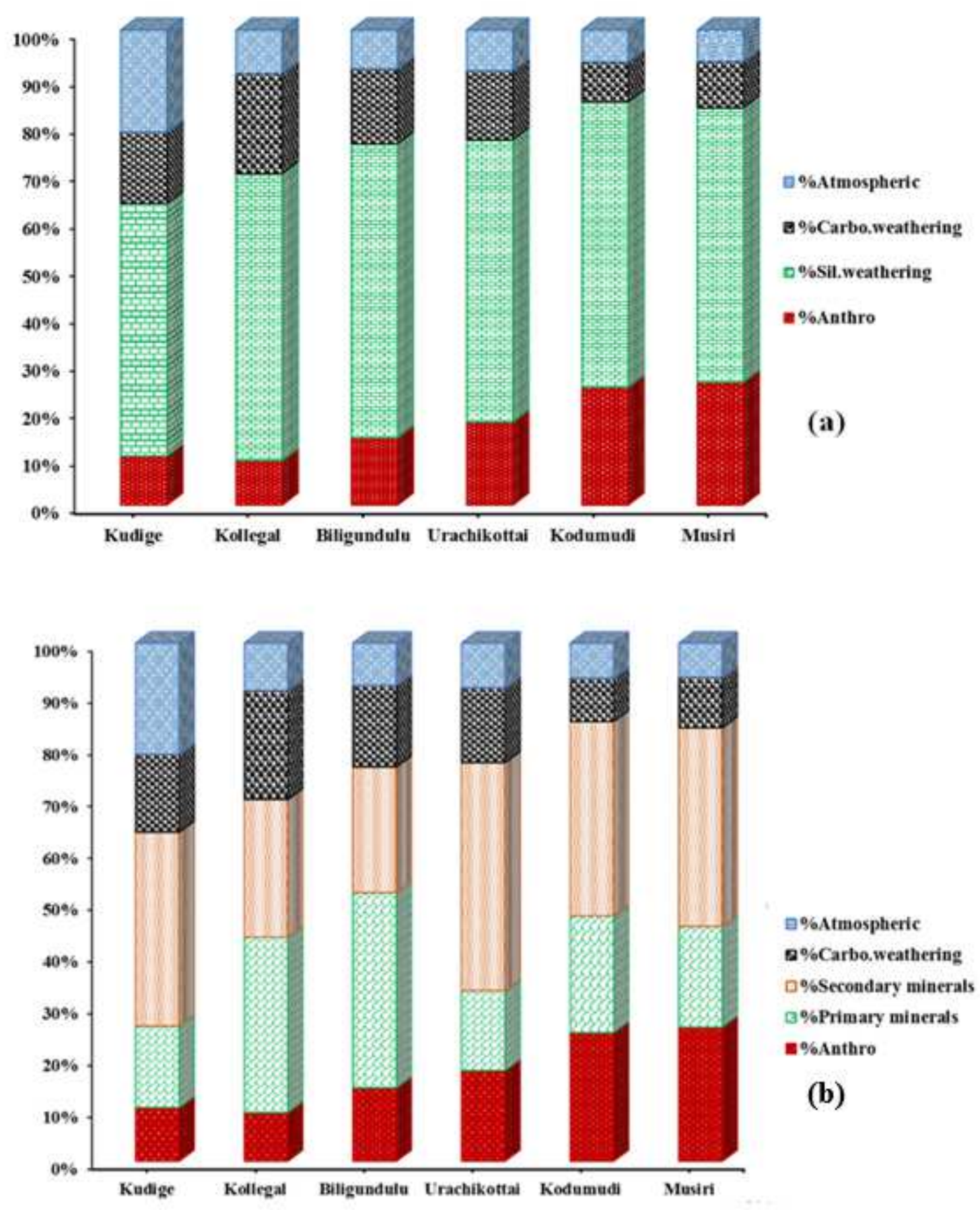

घ\%Atmospheric Q $\%$ Carboweathering $\square \%$ Secondary minerals [3\% Primary minerals m.Anthro

(b)

\section{Figure 6}

Source-wise solute load contributions (discharge weighted) to the total dissolved load of CRB from (a) atmospheric input, carbonate, silicate weathering and anthropogenic sources (b) atmospheric input, carbonate, secondary minerals, primary minerals weathering and anthropogenic sources, solute load of secondary minerals weathering $(35.5 \%)$ is significantly higher than the primary minerals $(23.5 \%)$, emphasizing the role of secondary soil minerals control over the CRB hydrochemistry.

\section{Supplementary Files}


This is a list of supplementary files associated with this preprint. Click to download.

- GraphicalAbstractEES.docx

- SupplyEES.docx 